\title{
Complementary Distribution of Receptors for Neurotensin and NPY in Small Neurons in Rat Lumbar DRGs and Regulation of the Receptors and Peptides after Peripheral Axotomy
}

\author{
X. Zhang, Z.-Q. Xu, L. Bao, Å. Dagerlind, and T. Hökfelt \\ Department of Neuroscience, Karolinska Institute, 17177 Stockholm, Sweden
}

\begin{abstract}
Neurotensin (NT) has been reported to have antinociceptive effects at the spinal level. In situ hybridization, electrophysiology, immunohistochemistry, and electronmicroscopy were used to investigate the distribution of NT receptors, possible effects of NT on primary sensory neurons, and the effect of nerve injury on the expression of NT receptors and NT. NT receptor $(R)$ mRNA was observed in more than $25 \%$ of the small dorsal root ganglion (DRG) neurons, which lacked neuropeptide Y NPY-R mRNA and essentially other neuropeptide mRNAs. Intracellular recording using voltage-clamp mode showed that NT evokes an outward current in NPY-insensitive small neurons, and NPY an outward current in NT-insensitive small neurons. Both peptides lacked effect on several small DRG neurons. In the superficial dorsal horn NT immunoreactive (IR) terminals directly contacted primary afferent terminals without synaptic specializations. This new category $(>25 \%)$ of the small DRG neurons expressing NT-R mRNA was complementary to the around $60 \%$ of small neurons expressing NPY-R mRNA (and also substance $P$ and calcitonin generelated peptide mRNAs) and to the rest exhibiting somatostatin mRNA expression. The electrophysiological results support this classification, showing that NT and NPY have inhibitory effects on separate subpopulations of small DRG neurons. After sciatic nerve transection, a marked decrease was observed in (1) the number of NT-R mRNA-positive neurons in DRGs, (2) NT mRNA-positive neurons in the dorsal horn, and (3) NT-IR cell bodies and fibers in laminae I-II. Thus, axotomy causes downregulation of several NT systems at the spinal level, suggesting that the possible effects of NT on primary sensory neurons is attenuated after peripheral axotomy.
\end{abstract}

[Key words: coexistence, calcitonin gene-related peptide, pain, plasticity, somatostatin]

Neurotensin (NT), a tridecapeptide (Carraway and Leeman, 1973, 1975), is widely distributed in the nervous system (Kobayashi et al., 1977; Emson et al., 1985), where it is an important regulatory molecule (see Kitabgi and Nemeroff, 1992). One region with many immunoreactive (IR) cell bodies and nerve ter-

\footnotetext{
Received Apr. 12, 1994; revised Sept. 29, 1994; accepted Oct. 3, 1994.

This work was supported by the Swedish MRC (04X-2887), the Bank of Sweden Tercentenary Foundation, Marianne and Marcus Wallenbergs Stiftelse and Gustav V:s and Drottning Victorias Stiftelse. We thank Dr. P. Frey, Sandoz Research Institute, Bern, Switzerland, for generous supply of NT antiserum

Correspondence should be addressed to T. Hökfelt at the above address.

Copyright (C) 1995 Society for Neuroscience $0270-6474 / 95 / 152733-15 \$ 05.00 / 0$
}

minals is the superficial dorsal horn of the rat spinal cord (Uhl et al., 1979; Gibson et al., 1981; Hunt et al., 1981; Ninkovic et al., 1981; Seybold and Elde, 1982; Seybold and Maley, 1984; Todd et al., 1992; Proudlock et al., 1993). Since NT has not been reported to be present in normal dorsal root ganglion (DRG) neurons, it has been assumed that the dense network of NT-IR fibers in the dorsal horn originates from the local neurons. However, low amounts of NT-like immunoreactivity (LI) may be present in a few primary afferent fibers in the dorsal horn under normal circumstances (Zhang et al., 1993b). Behavioral, neurophysiological, and pharmacological studies have indicated functional roles for NT in the dorsal horn. Thus, NT has been shown to have antinociceptive effects (Clineschmidt and McGuffin, 1979; Yaksh et al., 1982; Spampinato et al., 1988). Intrathecal administration of NT results in an increase in the nociceptive threshold as measured in the hot plate test and an increase in the latency in the acetic acid-induced writhing response (Yaksh et al., 1982; Spampinato et al., 1988). Morever, after peripheral axotomy, a marked decrease in NT-LI has been described in the dorsal horn of the monkey spinal cord (Zhang et al., 1993a), suggesting that NT may be involved in sensory mechanisms that may cause chronic pain. In order to better understand the role of NT at the spinal level and its possible involvement in syndromes accompanying peripheral nerve injury, we have analyzed the distribution of NT receptor InRNA, the effects of NT on sensory neurons, and the expression of NT and its receptors after axotomy.

NT binding sites have been observed in the brain (see Uhl, 1990) and also in the superficial dorsal horn of the spinal cord (Ninkovic et al., 1981; Young and Kuhar, 1981). No change in density or distribution of NT binding sites was found after dorsal root section (Ninkovic et al., 1981), suggesting that NT receptors (NT-Rs) are not present on the terminals of primary afferents. It has recently been shown that the NT-R is a member of the guanine nucleotide binding, G-protein-coupled receptor superfamily (Tanaka et al., 1990), and the cloning of its cDNA sequence (Tanaka et al., 1990) has allowed analysis of distribution of NT-R mRNA in the brain using in situ hybridization (Elde et al., 1990).

In the present study, in situ hybridization was used to analyze the localization of NT-R mRNA in DRG neurons of normal rats and after peripheral axotomy. Furthermore, it was attempted to define the relation of DRG neurons expressing NT-R mRNA to those recently described to contain neuropeptide tyrosine (NPY)-R mRNA (Jazin et al., 1993; Zhang et al., 1994a) as well as certain neuropeptide mRNAs. The effect of NT and NPY on DRG neurons was monitored with intracellular recordings using 
voltage-clamp mode. Finally, NT-LI and NT mRNA were studied in the superficial dorsal horn of normal rats and after peripheral axotomy.

The present results show that NT-R mRNA-positive neurons represent a unique subpopulation of small DRG neurons. Together with two other subpopulations containing NPY-R and somatostatin (SOM), respectively, they account for virtually all small DRG neurons. In agreement, small DRG neurons were sensitive either to NT or NPY or insensitive to both of these peptides. In the dorsal horn, NT-positive boutons of local neurons had direct, nonsynaptic contacts with primary afferent terminals. Finally, axotomy reduced NT-R mRNA levels in DRG neurons and NT-LI and NT mRNA in the superficial dorsal horn, suggesting that peripheral nerve injury causes a general downregulation of several NT systems at the spinal cord level.

\section{Materials and Methods}

In situ hybridization. Eighteen adult male Sprague-Dawley rats (body weight, 200-250 gm; ALAB, Stockholm, Sweden) were deeply anesthetized with sodium pentobarbital (Mebunal; $60 \mathrm{~m} \mathrm{~g} / \mathrm{kg}$, i.p.), and the left sciatic nerve was transected above trochanter major. In all cases, a $5 \mathrm{~mm}$ portion of the nerve was resected. The rats were allowed to survive for $2,7,21$, and $28 \mathrm{~d}$ (three rats in each group) or $14 \mathrm{~d}$ (six rats). Lesioned animals and three normal control animals were deeply anesthetized (as above) and perfused via the aorta with $50 \mathrm{ml}$ warm $\left(37^{\circ} \mathrm{C}\right)$ saline to clear the blood, followed by rapid dissection and freezing of L4 and L5 DRGs and L4-5 spinal cord segments. Before sectioning, experimental and normal DRGs or spinal cords were fused by saline on the same blocks, so that all groups could be processed on the same slide. Sections $(14 \mu \mathrm{m})$ were cut in a cryostat (Microm, Heidelberg, Germany) and thawed onto "Probe On" slides (Fisher Scientific, Pittsburgh, PA) and stored in sealed boxes at $-20^{\circ} \mathrm{C}$ until hybridization. A separate block containing two ipsilateral and two control L5 DRGs were cul at $5 \mu$ m thickness, and series of these sections were collected in the same way as described above.

Oligonucleotide probes were purchased from Scandinavian Gene Synthesis AB (Köping, Sweden). A mixture of three 48-mer oligonucleotides complementary to, respectively, nucleotides $175-222,304$ 351, and 1150-1197 of the rat NT-R (Tanaka et al., 1990), and an oligonucleotide complementary to the nucleotides $546-585$ of the rat NPY Y1-R (Eva et al., 1990) were used. Sequences for peptide oligonucleotides were complementary to nuclentides 549-596 of rat NT (Kislauskis et al., 1988), nucleotides 152-199 of rat galanin (GAL) (Vrontakis et al., 1987), nucleotides 145-192 of rat substance P (SP) (Krause et al., 1987), nucleotides 351399 of rat SOM (Goodman et al., 1989), and nucleotide $664-698$ of rat calcitonin gene-related peptide (CGRP) (Amara et al., 1985). The oligonucleotide probes were labeled at the $3^{\prime}$ end with $\alpha{ }^{-35}$ S-dATP (New England Nuclear, Buston, MA) using (erminal deoxynucleotidyl transferase (Amersham, Amersham, UK) in a buffer containing $10 \mathrm{mM} \mathrm{CoCl}_{2}, 1 \mathrm{~mm}$ dithiothreitol (DTT), $300 \mathrm{~mm}$ Tris base, and $1.4 \mathrm{M}$ potassium cacodylate $(\mathrm{pH} 7.2)$. Afterward, the labeled probes were purified through Nensorb-20 columns (New England Nuclear), and DTT was added to a final concentration of $10 \mathrm{mM}$. The specific activities obtained ranged from $1-4 \times 10^{6} \mathrm{cpm} / \mathrm{ng}$ oligonucleotide.

Our procedure followed previously published protocols (Dagerlind et al, 1992). Sections were hybridized after thawing without pretreatment for $16-18 \mathrm{hr}$ at $42^{\circ} \mathrm{C}$ in humidified boxes with $10^{\circ} \mathrm{cpm}$ of labeled probe per $100 \mu \mathrm{l}$ of a mixture containing: $50 \%$ formamide (G. T. Baker Chemicals BW, Deventer, The Netherlands); $4 \times$ SSC $(1 \times$ SSC $=0.15 \mathrm{M}$ $\mathrm{NaCl}$ and $0.015 \mathrm{M}$ sodium citrate); $1 \times$ Denhardt's solution $(0.02 \%$ each of polyvinylpyrrolidone, bovine serum albumin, and Ficoll); $1 \%$ sarkosyl ( $N$-lauryl sarcosine; Sigma, St. Louis, MO); $0.02 \mathrm{M}$ phosphate buffer ( $\mathrm{pH} 7.0$ ); 10\% dextran sulphate (Pharmacia, Uppsala, Sweden); $500 \mu \mathrm{g} / \mathrm{ml}$ sheared and heat-denatured salmon testis DNA (Sigma); and $200 \mathrm{~mm}$ dithiothreitol (DTT; LKB, Bromma, Sweden). After hybridization, the sections were rinsed repeatedly $(4 \times 15 \mathrm{~min})$ in $1 \times \mathrm{SSC}$ at $55^{\circ} \mathrm{C}$, then brought to room temperature over $30 \mathrm{~min}$ while in the final rinse, dipped twice in distilled water, dehydrated through $60 \%$ and $95 \%$ ethanol, and dried in air. The slides were dipped in NTB2 nuclear track emulsion (Kodak, Rochester, NY) diluted 1:1 with distilled water, exposed in the dark at $-20^{\circ} \mathrm{C}$ for $4-6$ weeks, developed in D-19 (Kodak) for $3 \mathrm{~min}$, fixed in Kodak 3000A\&B for $6 \mathrm{~min}$, and rinsed for $30 \mathrm{~min}$ in running water. Developed slides were mounted with glycerol and coverslipped for analysis in a Nikon Microphot-FX microscope equipped with a dark-field condenser or stained with Toluidine blue, mounted with Entellan (Merck, Darmstadt, Germany) and a coverslip for viewing under bright-field.

For control hybridizations were carried out with an excess of cold probe $(100-$ fold) together with the labeled probe.

Quantification. To determine the percentage of labeled neurons, counts were done on sections stained with Toluidine blue. Four to eight sections (14 $\mu \mathrm{m}$ thick) of L5 DRGs from three control animals and three injured animals of each time point were processed. The sections were examined under bright-field using a $20 \times$ objective lens. We divided the size of DRG neuron profiles into small, medium-sized, and large ones. Small neuron profiles were $22-32 \mu \mathrm{m}$ in diameter with nucleus and dark cytoplasm, medium-sized ones were $32-50 \mu \mathrm{m}$ in diameter (longest diameter) with a nucleus and dark cytoplasm, and large ones had a diameter larger than $50 \mu \mathrm{m}$ with a nucleus or a diameter of $40-50 \mu \mathrm{m}$ without nucleus and with light cytoplasm. Neurons with three times more grains than mean background grain densities were counted. Mean background grain densities $\left(0-5\right.$ grains per $\left.100 \mu \mathrm{m}^{2}\right)$ were determined by averaging grain counts over defined areas of the neuropil devoid of positively labeled cell bodies. Five hundred and fifty to 820 neurons from the sections of each DRG of each animal of the two groups were analyzed. The total number of labeled neuron profiles was divided by the total number of toluidine blue-stained neuron profiles.

To determine the size of DRG neurons positive for NT-R or NPY-R mRNAs, 200 positive ncurons for cach receptor mRNA and 500 DRG neurons were randomly selected and measured on lightly toluidine bluestained sections. A Macintosh IIx equipped with a DAGE-MTI CCD72 series camera connected with a Nikon Microphot-FX microscope equipped with a $20 \times$ objective lens was used to collect the data. IMAGE version 1.16 was used to measure the area of the cell profiles expressed as square micrometers; an area less than $900 \mu \mathrm{m}^{2}$ micrometers corresponds to small neurons (diameter $<32 \mu \mathrm{m}$ ) (see Giuffrida and Rustioni, 1992).

In order to describe the changes in expression of NT mRNA in dorsal horn neurons after peripheral axotomy, we divided laminae II and III into four fields $(\Lambda 1,2,3$, and 4 , from medial to lateral), and every second slide (totally 10 slides) of three normal rats and of rats 2,7 , and $14 \mathrm{~d}$ after axotomy (three in each group) was analyzed. The total number of NT mRNA-positive neurons in each area of lanina II and the superficial lamina III were counted. Moreover, the neurons were classified as densely labeled (number of grain $>60$ per cell body), moderately labeled (34-60 per cell body), and lightly labeled (24-34 per cell body). The diameter of NT mRNA-positive cell bodies in dorsal horn was $8-10 \mu \mathrm{m}$. The number of grains over background was $0-8$ per $100 \mu \mathrm{m}^{2}$. Camera lucida plots of the location of NT mRNA-positive neurons were made for each spinal cord, and the data were presented on one drawing of the dorsal horn for each time point. All data were processed for one-tail unpaired $t$ test. Results were presented as mean \pm standard error of mean (SEM).

Northern blot analysis. Approximately $200 \mathrm{mg}$ frozen tissue (40 L4 and L5 DRGs) from both control rats and $14 \mathrm{~d}$ after bilaterally sciatic nerve cut rats were placed in a solution containing $4 \mathrm{M}$ guanidine isothiocyanate, $0.1 \mathrm{M} \beta$-mercaptoethanol, $0.025 \mathrm{~m}$ sodium citrate $(\mathrm{pH} \% .0)$, and immediately homogenized with a Polytrone. Each tissue homogenate was layered over a $4 \mathrm{ml}$ cushion of $5.7 \mathrm{M} \mathrm{CsCl}$ in $0.025 \mathrm{M}$ sodium citrate ( $\mathrm{pH} 5.5$ ) and centrifuged at $20^{\circ} \mathrm{C}$ in a Beckman SW41 rotor at $35,000 \mathrm{rpm}$ for $18 \mathrm{hr}$. The recovery of total RNA was quantified spectrophotometrically at $260 \mathrm{~nm}$, and $15 \mu \mathrm{g}$ of total RNA from each sample were separated on a $1 \%$ agarose gel containing $0.7 \%$ paraformaldehyde, blotted onto Hybond-N membranes and cross linked by UV illumination. Membranes werc prchybridized at $42^{\circ} \mathrm{C}$ for $6-8 \mathrm{hr}$ in a solution containing $50 \%$ formamide, $5 \times$ SSPE $(1 \times$ SSPE $=0.15 \mathrm{M}$ sodium chloride, $0.01 \mathrm{M}$ sodium dihydrogen phosphate monohydrate, 1 mM EDTA), $0.1 \%$ sodium dodecyl sulfate (SDS), $2 \times$ Denhardt's (as above), and $200 \mu \mathrm{g} / \mathrm{ml}$ of sheared and heat denatured salmon testis DNA. Eight nanograms of ${ }^{32} \mathrm{P}$-labeled $\left(2-4 \times 10^{9} \mathrm{cpm} / \mu \mathrm{g}\right)$ oligonucleotide NT receptor probe or NPY (Y1) receptor probe (same as the ones used for in situ hybridization) per milliliter of hybridization solution were added, and the incubation was continued for an additional $18-20$ $\mathrm{hr}$ at $42^{\circ} \mathrm{C}$. Membranes were washed in $2 \times$ SSPE and $0.1 \%$ SDS $(2 \times$ $10 \mathrm{~min}$ at $\left.55^{\circ} \mathrm{C}\right), 1 \times \mathrm{SSPE}$ and $0.1 \%$ SDS $\left(1 \times 20 \mathrm{~min}\right.$ at $\left.55^{\circ} \mathrm{C}\right)$ and 

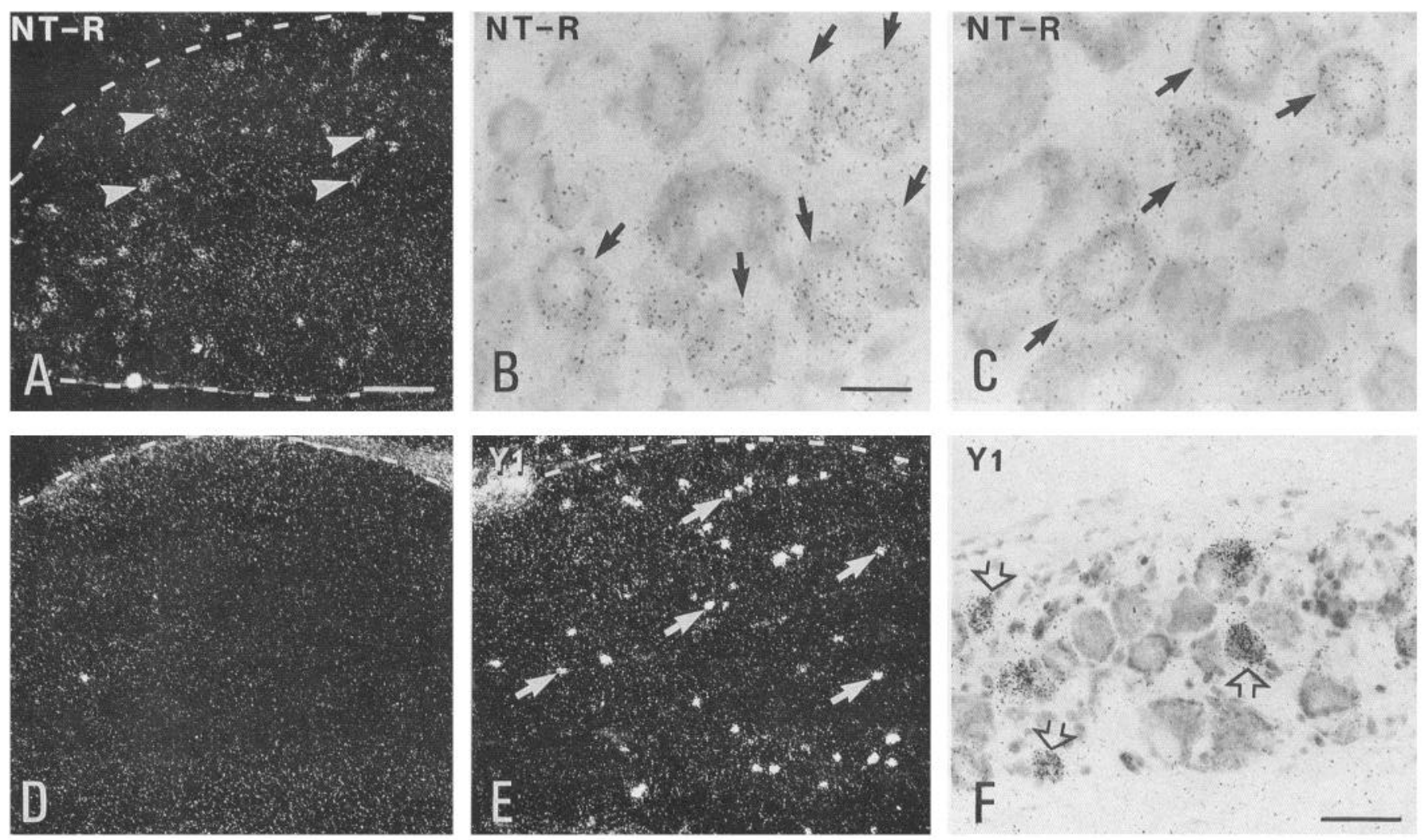

Figure 1. $A-F$, Dark-field $(A, D, E)$ and bright-field $(B, C, F)$ micrographs of control L5 DRGs hybridized with a probe for NT-R mRNA $(A-$ $C$ ), a probe for NT-R mRNA plus an 100 -fold excess of 'cold' probe $(D)$, and a probe for NPY Y1 receptor mRNA $(E, F)$. Labeling for NT-R mRNA is observed in many small neurons (arrowheads in $A$ and arrows in $B, C$ ). Strong labeling of Y1 receptor mRNA is observed in many small neurons (arrows in $E$ and open arrows in $F$ ). An excess of cold probe completely abolished the NT-R mRNA signal (D). Scale bars: 200 $\mu \mathrm{m}$ in $A, D$, and $E ; 20 \mu \mathrm{m}$ in $B$ and $C ; 50 \mu \mathrm{m}$ in $F$.

$0.1 \times$ SSPE and $0.1 \% \operatorname{SDS}(2 \times 10 \mathrm{~min}$ at room temperature $)$ and exposed to film (Kodak X-Omat) with intensifying screens at $-70^{\circ} \mathrm{C}$ for 1-2 weeks.

Immunofluorescence. Fifteen male Sprague-Dawley rats (body weight, $250-300 \mathrm{gm}$ ) were anesthetized (as above) and received a unilateral sciatic nerve transection (as above). The animals were allowed to survive for $2,7,14,21$, and $28 \mathrm{~d}$. Operated animals and four normal male rats used as controls were deeply anesthetized and perfused transcardially with warm $\left(37^{\circ} \mathrm{C}\right), \mathrm{Ca}^{2+}$-free Tyrode's solution followed by a fixative containing $4 \%$ paraformaldehyde, $0.2 \%$ picric acid in $0.16 \mathrm{M}$ phosphate buffer $(\mathrm{PB})$ for $6 \mathrm{~min}$. The spinal cord lumbar segments and L4 and L5 DRGs were quickly dissected out, immersed in the same fixative for $90 \mathrm{~min}$, and then immersed in $10 \%$ sucrose buffer solution containing $0.01 \%$ sodium azide and $0.02 \%$ bacitracin (Bayer, Leverkusen, Germany) for at least $24 \mathrm{hr}$.

The spinal cord (L4 and L5 segments) and DRGs (L4-5) were cut in $14 \mu \mathrm{m}$ thick sections in a cryostat (Dittes, Heidelberg, Germany) and processed according to the indirect immunofluorescence technique.
Briefly, the sections were incubated overnight at $4^{\circ} \mathrm{C}$ in a humid chamber with rabbit antiserum against NT (1:1600; Frey et al., 1988), rinsed, incubated with FITC-conjugated goat anti-rabbit antibodies (dilution 1:80, Boehringer-Mannheim Scandinavia, Stockholm, Sweden) for 30 min in a humid atmosphere at $37^{\circ} \mathrm{C}$, mounted in a mixture of glycer$\mathrm{ol} / \mathrm{PBS}(3: 1)$ containing $0.1 \% p$-phenylenediamine, and examined in a Nikon Microphot-FX microscope equipped with epifluorescence and proper filter combinations.

The specificity of the NT antiserum was tested by absorption with synthetic NT (Peninsula, Belmont, CA) at a concentration of $1 \mu \mathrm{M}$ for $24 \mathrm{hr}$ at $4^{\circ} \mathrm{C}$.

Immunoelectronmicroscopy. Four male Sprague-Dawley rats $(200-$ $250 \mathrm{gm}) 14 \mathrm{~d}$ after unilateral sciatic nerve cut (as above) and four normal rats were anesthetized (as above) and perfused as above, but with $0.1 \%$ glutaraldehyde added. The L4-5 spinal segments were then dissected and postfixed in the same fixative for $36 \mathrm{hr}$ at $4^{\circ} \mathrm{C}$. Vibratome ${ }^{\circledR}$ sections of the spinal cord were cut at $50 \mu \mathrm{m}$ and subjected to freezethaw treatment. The sections were incubated in rabbit antiserum against

Table 1. Percentage of small (S), medium-sized (M), and large (L) neurotensin receptor mRNA-positive neuron profiles, respectively, in control, contralateral (Contra), and ipsilateral (Ipsi) L5 DRGs, 2, 7, 14, 21, and $28 \mathrm{~d}$ after sciatic nerve transection

\begin{tabular}{|c|c|c|c|c|c|c|c|c|c|c|c|}
\hline \multirow{2}{*}{$\begin{array}{l}\text { Cell } \\
\text { Type }\end{array}$} & \multirow[b]{2}{*}{ Control } & \multicolumn{2}{|l|}{2 days } & \multicolumn{2}{|l|}{7 days } & \multicolumn{2}{|l|}{14 days } & \multicolumn{2}{|l|}{21 days } & \multicolumn{2}{|l|}{28 days } \\
\hline & & Contra & Ipsi & Contra & Ipsi & Contra & Ipsi & Contra & Ipsi & Contra & Ipsi \\
\hline S & 28.1 & 26.0 & 2.1 & 26.7 & 1.8 & 24.8 & 4.2 & $23.1 \pm 2.5$ & $2.8=$ & $26.4 \pm 2.0$ & $1.7^{* *}$ \\
\hline M & $5.3 \pm 1.5$ & $4.2 \pm 0.5$ & $0.5 \pm 0.3^{* *}$ & $3.9 \pm 0.4$ & $0.2 \pm 0.1^{* *} *$ & $3.4 \pm 0.8$ & $1.7 \pm 0.5^{* *}$ & $4.0 \pm 1.7$ & $0.3 \pm 0.2 * *$ & $3.8 \pm 0.5$ & $0.2 \pm 0.2^{\text {** }}$ \\
\hline L & $1.1 \pm 0.2$ & $0.8 \pm 0.5$ & $0.0 \pm 0.0^{* *}$ & $0.6 \pm 0.3$ & $0.0 \pm 0.0^{* *}$ & $0.7 \pm 0.3$ & $0.0 \pm 0.0^{* *}$ & $0.3 \pm 0.1$ & $0.0 \pm 0.0^{* *}$ & $0.4 \pm 0.1$ & $0.0 \pm 0.0^{* * *}$ \\
\hline
\end{tabular}

Three control rats and three lesioned rats were analyzed. At least 550 neurons were counted in each DRG of each animal. Data were analyzed with one-tailed unpaired $t$-test, and results are shown with mean \pm SEM

$* * p<0.01$. 

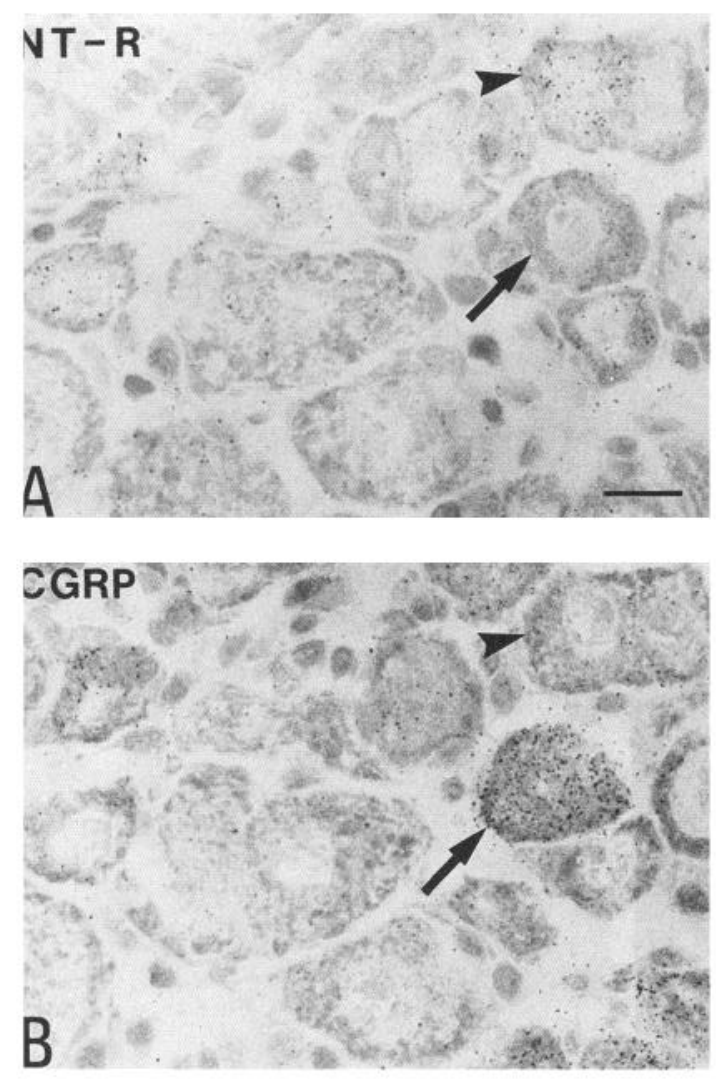
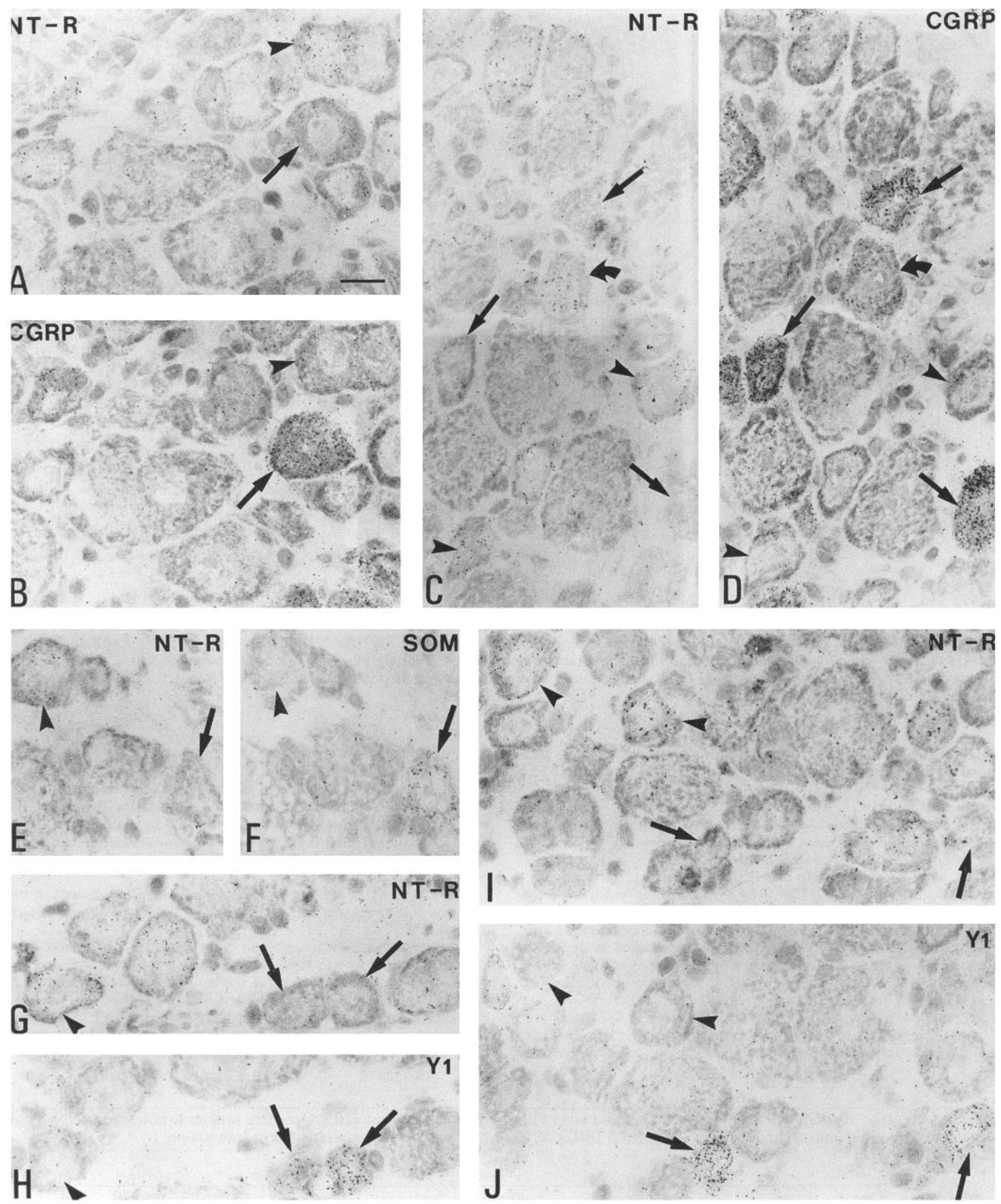

$\mathrm{H}$

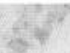

Y1

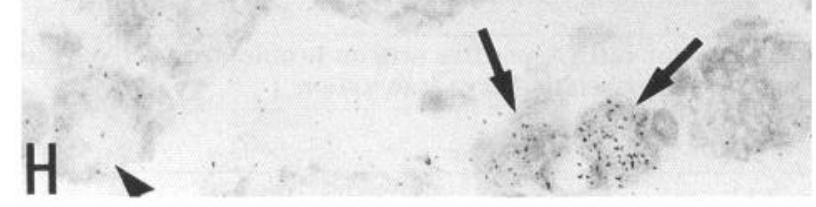

Figure 2. A-J, Groups of two $5 \mu \mathrm{m}$ thick adjacent sections of control L5 DRG hybridized with probe for NT-R mRNA $(A, C, E$, $G, I)$, or with probes for mRNA for CGRP $(B, D)$, SOM $(F)$, and NPY Y1-R $(H, J)$. Many small neurons are CGRP-positive and NT-negative (arrows in $A-D)$ and some are NT-positive and CGRP-negative (arrowheads in $A-D$ ). Low levels of CGRP mRNA colocalize with NT-R mRNA in a few small neurons (curved arrows in $C, D$ ). SOM mRNA is not detected in NT-R mRNA-positive small neurons (arrows and arrowheads in E, $F$ ). Many small neurons contain either NT-R mRNA (arrowheads in $G, I$ ), or Y1 receptor mRNA (arrows in $H, J$ ). Scale bar, $20 \mu \mathrm{m}$. 
A

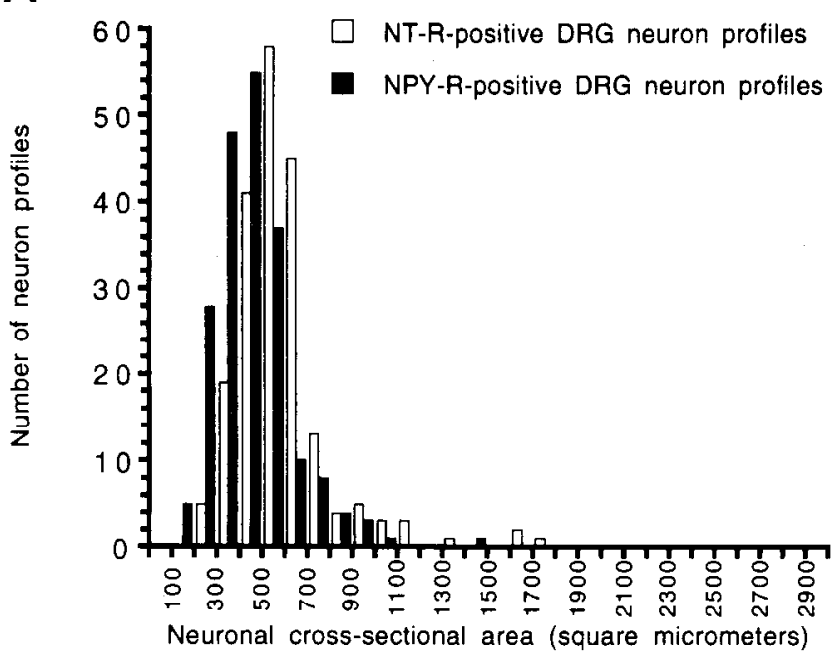

$\mathbf{B}$

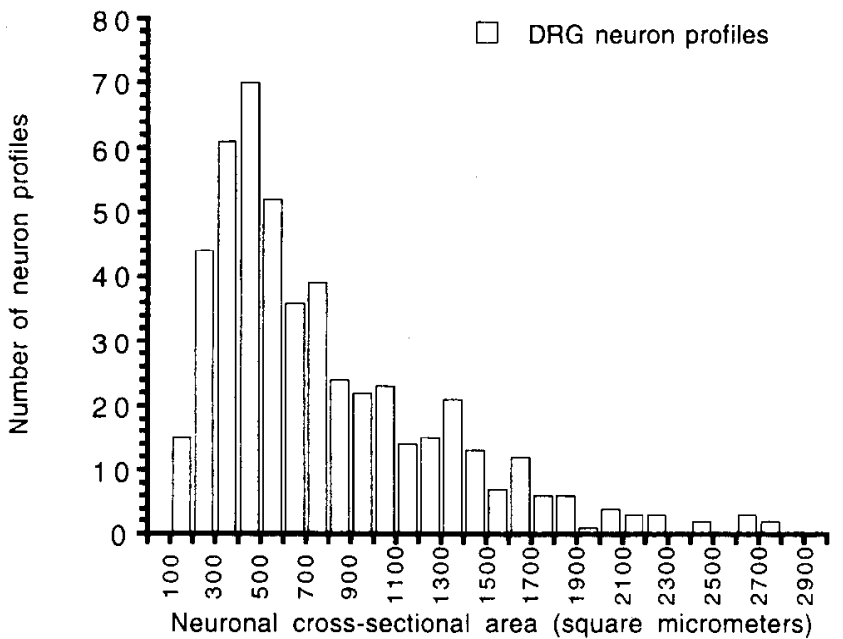

Figure 3. $A$ and $B$, Histograms of number of DRG neuron profiles versus surface area of NT-R or NPY-R mRNA-positive neuron profiles $(n=200)(A)$ and toluidine blue DRG neuron profiles $(n=500)(B)$ $A$, Within the range of small neuron profiles $\left(900 \mu \mathrm{m}^{2}\right.$; see Giuffrida and Rustioni, 1992), the size of NT-R mRNA-positive neuron profiles is generally larger than the size of NPY-R mRNA-positive neuron profiles. B, Most NT-R and NPY-R mRNAs-positive neurons are in the range of small neuron profiles (compare with $A$ ).

NT (1:1600; Frey et al., 1988) for 36 hr at $4^{\circ} \mathrm{C}$ followed by biotinylated goat anti-rabbit IgG (1:200), then stained with avidin-biotin-peroxidase complex (1:100; Vector ABC kit, Vector, Burlingame, $C A)$, visualized by the glucose oxidase-3,3-diaminobenzidine method. Briefly, the sections were incubated for $15-25 \mathrm{~min}$ in a medium containing $60 \mathrm{mg} \mathrm{3,3-}$ diaminobenzidine, $200 \mathrm{mg}$ of glucose, $40 \mathrm{mg}$ of ammonium chloride, and $0.7 \mathrm{mg}$ glucose oxidase (Sigma, type VII) in $100 \mathrm{ml}$ of $0.01 \mathrm{M}$ PBS. The sections were postfixcd in $1 \%$ osmium tetroxide at $4{ }^{\circ} \mathrm{C}$ for $30 \mathrm{~min}$. Dehydration was carried out in increasing concentrations of ethanol. After passing through propylene oxide and incubation in Epon 812, the sections were flat embedded in Epon 812 between two sheets of plastic film. The superficial dorsal horn containing NT-LI was identified under the light microscope and mounted on blank resin stubs. Ultrathin sections were cut on an LKB III ultratome, counterstained with uranyl acetate and lead citrate, and examined in a JEOL 1200 EX electron microscope.

For the quantitative analysis of NT-IR terminals ultrathin sections of the dorsal horns from two rats were analyzed. Only NT-positive boutons forming distinct synapses with dendrites or being directly in contact (without synapse) with identifiable central terminals of a glomerulus were counted. NT-IR terminals were randomly selected and analyzed.

Electrophysiology. Sprague-Dawley rats (body weight, 100-200 gm) were lightly anesthetized with diethyl ether and decapitated. The L4 and L5 DRG were quickly removed from both sides of the rat. The ganglia were kept at room temperature in oxygenated artificial cerebrospinal fluid (aCSF). For recording, a ganglion was transferred to a submersion type chamber, through which aCSF $(1.5 \mathrm{ml} / \mathrm{min})$ saturated with $95 \% \mathrm{O} / 5 \% \mathrm{CO}_{2}$ at $35-37^{\circ} \mathrm{C}$ was perfused. The aSCF contained (in mM) $124 \mathrm{NaCl}, 2.5 \mathrm{KCl}, 1.3 \mathrm{MgSO}_{4}, 1.24 \mathrm{NaH}_{2} \mathrm{PO}_{4}, 2.4 \mathrm{CaCl}_{2}, 25 \mathrm{NaHCO}_{3}$, and 10 glucose. The DRG was stabilized by gently pressing a gold electron microscopic grid, held in a micromanipulator, down on the DRG. Cell impalements were made with glass microelectrodes filled with $2 \mathrm{M}$ potassium chloride (DC. resistances, 35-65 M $\Omega$ ). Conventional intracellular recordings were made using the bridge balance or discontinuous single-electrode voltage clamp mode on an Axoclamp $2 \mathrm{~A}$ amplifier ( $\Lambda$ xon Instruments, Foster City, $C A$ ). Physiological data were accepted from neurons that had a resting membrane potential of at least $-45 \mathrm{mV}$. All data were stored on an IBM-compatible computer for online and off-line analysis with pcLAme software (Axon Instruments).

Synthetic NT (Bachem, Bubendorf, Switzerland) and NPY (Peninsula) were dissolved in aCSF. All drugs were bath applied by turning a three-way valve that switched from aCSF to the test solution. All data are expressed as mean \pm standard error of mean.

\section{Results}

\section{Complementary distribution of NT-R and NPY-R $m R N A s$ in normal DRGs}

In situ hybridization histochemistry showed that in control lumbar (L4 and L5 DRGs), about $23.0 \pm 1.4 \%$ of all counted neuron profiles were NT-R mRNA positive (Figs. $1 A-C, 2 A, C, E$, $G, I$ ). The majority were small neurons. About $28 \%$ of all counted small neuron profiles contained NT-R mRNA (Table 1). Only a few medium-sized and large neuron profiles were found to contain NT-R mRNA.

Colocalization of NT-R mRNA with NPY-R mRNA and some neuropeptide mRNAs was studied on $5 \mu \mathrm{m}$ thick, serial sections of control rat L5 DRGs. Many small- and medium-sized neuron profiles and some large ones were CGRP mRNA positive (Fig. 2B,D), many small- and medium-sized neuron profiles were SP mRNA positive, a few small neuron profiles expressed GAL mRNA, and some small ones were SOM mRNA positive (Fig. 2F). Y1-R mRNA was observed in many small neuron profiles and also in a few medium-sized ones (Figs. $1 E, F ; 2 H, J$ ). A few NT-R mRNA-positive small neuron profiles contained CGRP mRNA (Fig. 2C,D). The intensity of labeling for CGRP mRNA was always lower in NT-R mRNA-positive neurons than in the neurons lacking a NT-R mRNA signal (Fig. $2 A-D$ ). The vast majority of CGRP mRNA-positive neurons did not contain NT-R mRNA. NT-R mRNA was not observed in SP, GAL, or SOM (Fig. 2E,F) mRNA-positive small neurons. NT-R mRNApositive neurons were not found to contain Y1-R mRNA (Fig. $2 G-J$ ). In contrast, Y1-R mRNA colocalized with CGRP and SP mRNAs in many small neurons (see also Zhang et al., 1994). Among small DRG neuron profiles, the size of NT-R mRNApositive profiles was generally larger than NPY-R mRNA-positive ones (Fig. $3 A, B$ ).

The quantiative analysis showed that almost two-thirds $(59.3$ $\pm 5.7 \%$ ) of the counted profiles were CGRP mRNA positive, and NT-R mRNA was only found in $3.3 \%$ of these profiles ( $n$ $=99$ NT-R mRNA-positive profiles). Y1 receptor mRNA was observed in $94.9 \%$ of the counted CGRP mRNA-positive profiles. About $40 \%(42.7 \pm 1.0 \%)$ of the counted profiles were SP mRNA positive, but none NT-R mRNA positive ( $n=86$ NT-R mRNA-positive profiles). Y1-R mRNA was observed in 
Figure 4. Characteristics of A-and C-type DRG cells. $A$, The top panel depicts the membrane-voltage responses to a series of incremental current injections recorded from a typical A-type cell. Note the prominent time-dependent rectification with the more hyperpolarizing currents and tail currents at the end of hyperpolarizing pulses. The bottom panel is the injected current. $B$, The same recordings as in $A$, but from a typical C-type cell. Note the lack of time-dependent rectification, the diminished rectification of inward or outward current injection, and the low threshold current injection required to excite a somatic action potential.
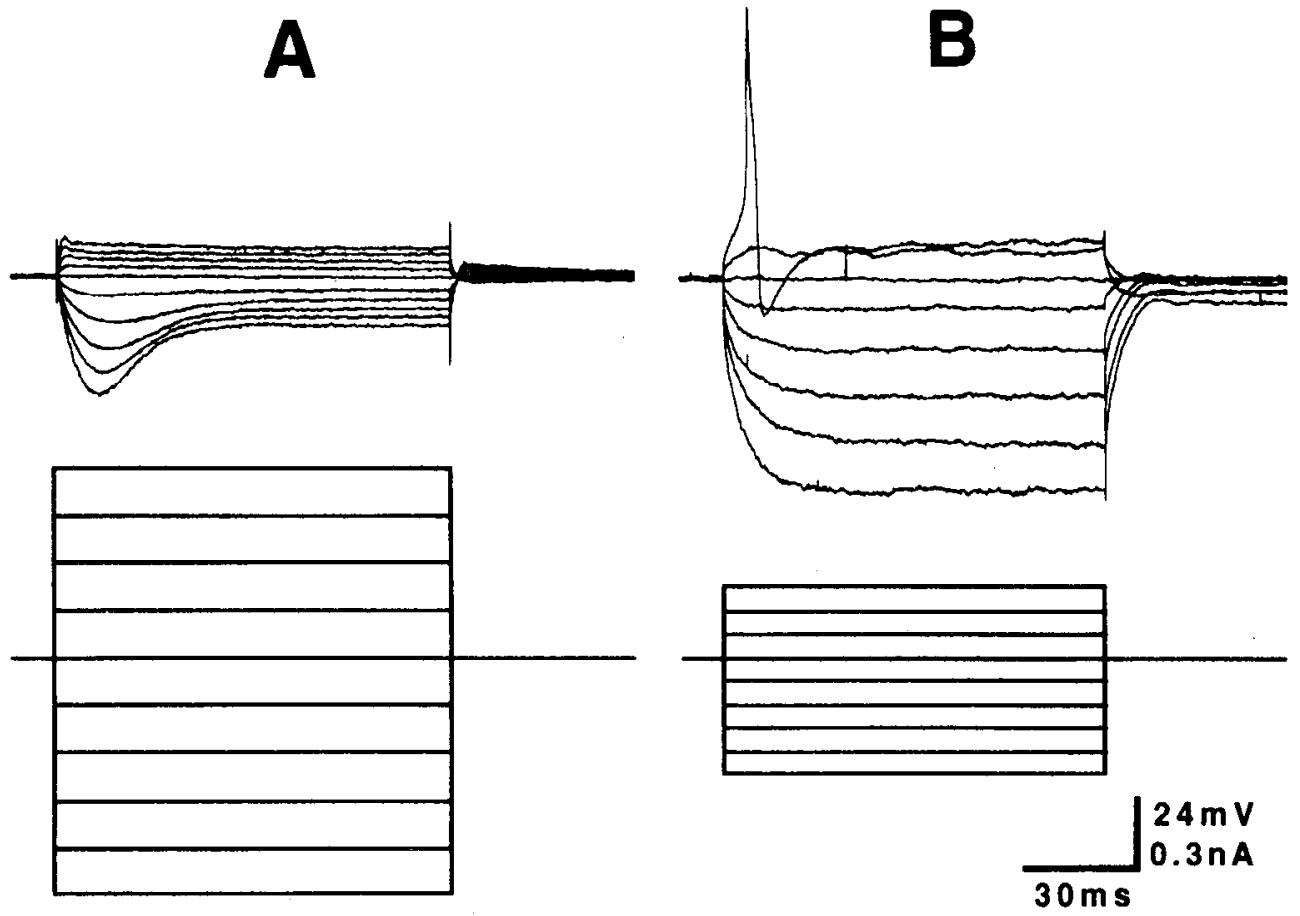

96.3\% of the counted SP mRNA-positive profiles. About $13 \%$ $(13.4 \pm 2.4 \%)$ of the counted profiles were SOM mRNA positive. Neither NT-R mRNA nor Y1 mRNA was detected in SOM mRNA-positive profiles ( $n=90$ NT-R mRNA-positive profiles). More than half $(54.0 \pm 3.4 \%)$ of the counted profiles were Y1-R InRNA positive, but NT-R mRNA was not detected in any of them ( $n=107$ NT-R mRNA-positive profiles).

No NT-R mRNA-positive neurons were detected in the dorsal horn of L4 and L5 spinal cord.

The control experiments revealed that an excess of cold probe completely abolished the signal from the various mRNAs as examplified in Figure $1 D$.

\section{$N T$ and NPY act on separate subpopulations of DRG neurons}

Intracellular recording was used to study the effects of NT and NPY on DRG neurons. After impalement of a cell and achievement of a stable recording, an increment series of $100 \mathrm{msec}$ current pulses (current steps were selected by pCLAMP computer software) were injected through the microelectrode in current-clamp mode. $R_{\text {in }}$ was measured from the slope of the $I / V$ curves. In response to current injection, 39 of 65 cells showed a time-dependent rectification, with the maximal voltage deflection relaxing over time, and a prominent tail voltage appearing at the end of the pulse. When depolarized, most of the cells of this group demonstrated strong membrane rectification with decreasing $R_{\text {in }}$. In these cells the $R_{\text {in }}$ ranged from 5 to $42 \mathrm{M} \Omega$ (mean $18.3 \pm 1.05 \mathrm{M} \Omega ; n=39$ ) (Fig. $4 A$ ). Thus, they behaved like A-type neurons as earlier described (Harper and Lawson, 1985a,b; Todorovic and Anderson, 1992). Another group of 26 cells had a higher $R_{\text {in }}$ (range from 50 to $101 \mathrm{M} \Omega$ mean $63.8 \pm$ $12.3 \mathrm{M} \Omega ; n=25$ ), lacked time-dependent rectification, showed less rectification when current was injected in the depolarizing direction, and exhibited action potentials upon low threshold direct somatic stimulation (Fig. $4 B$ ). Thus, these neurons behaved like C-type neurons (Harper and Lawson, 1985a,b; Todorovic and Anderson, 1992).

Analysis of response patterns in C-type neurons under volt- age-clamp conditions showed that NT $(1 \mu \mathrm{M})$ after bath application induced an outward current (amplitude from 40 to $85 \mathrm{pA}$ ) in 7 of 26 tested cells. The current was produced approximately 2-3 min after the addition of NT to the artificial cerebrospinal fluid (aCSF) bathing the ganglion. Within 2-6 min after return to control aCSF (without NT), the membrane current was back to baseline (Fig. $5 A)$. NPY $(0.5$ or $1 \mu \mathrm{M})$ induced an outward current (40-110 pA) in 12 of 26 tested cells. This effect was fast in onset, lasted over a period of 3-8 $\mathrm{min}$, and recovered after 5-10 min wash out with control aCSF (Fig. 5B). When NT and NPY were separately applied to the same cell $(n=26)$, NT induced an outward current in seven cells but NPY had no effect on these cells (Fig. 5A). In 12 cells, NPY induced an outward current, but no effect was recorded for NT on these cells (Fig. $5 B$ ). In seven cells, neither NT nor NPY had an effect. This suggests that C-type cells may be exclusively sensitive to one of the two peptides, NT or NPY.

The response patterns in A-type neurons were analyzed after application of NT $(1 \mu \mathrm{M})$ and NPY $(1 \mu \mathrm{M})$, respectively. When NT was applied, an inward current (amplitude 100 to $200 \mathrm{pA}$ ) was evoked in 14 of 31 tested cells. The effect was fast in onset and lasted over a period of 6-10 min (Fig. 5C). However, an outward current was observed in only one A-type cell. Sixteen neurons did not respond to NT. NPY ( $1 \mu \mathrm{M})$ evoked an outward current in 4 of 25 tested cells, and no response was seen in 21 neurons. None of the eight NT-responsive A-type neurons tested had any response to NPY (Fig. 5C), and the single NPY-responsive neuron that was tested had no response to NT. It is therefore possible that also the A-type cells show selectivity in their sensitivity to two peptides tested.

\section{NT-IR spinal neurons might be the major source of NT acting on DRG neurons}

Immunoelectron microscopy showed that many NT-IR dendrites were seen in laminae I, II, and the superficial lamina III of the dorsal horn of normal L4-5 spinal cord, and they received synapses from NT-negative axonal terminals (data not shown). 

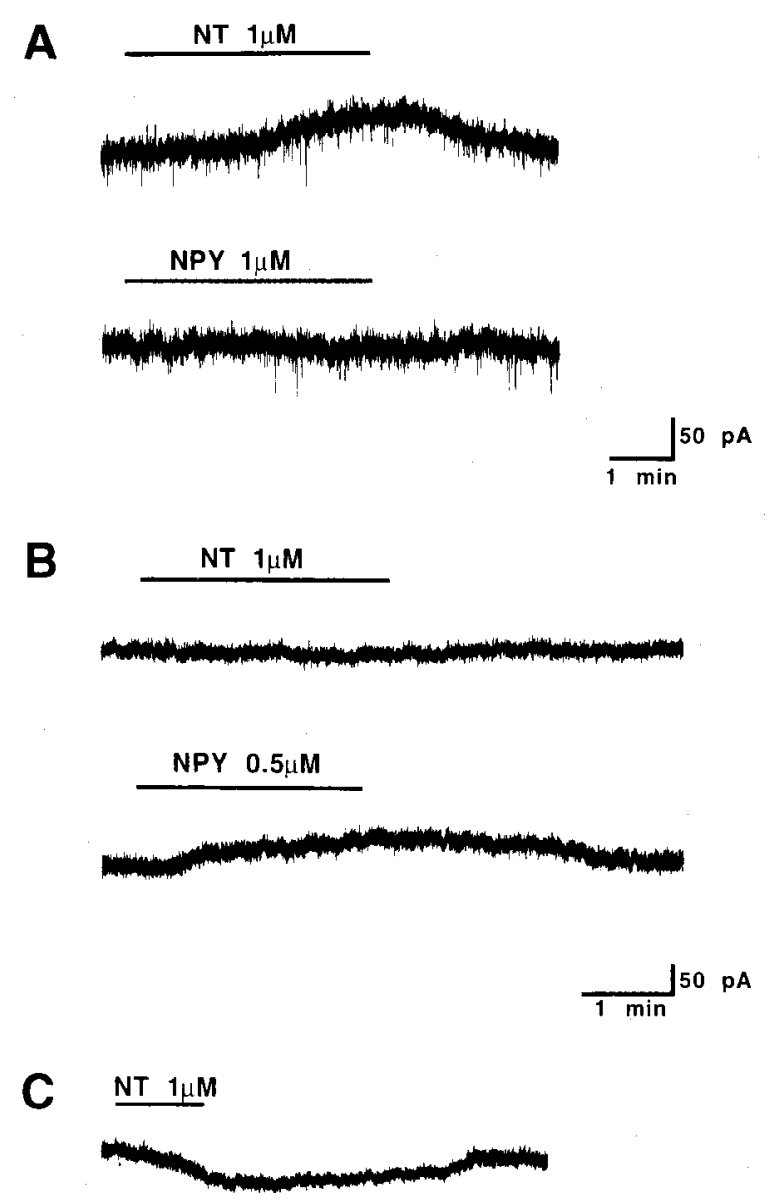

NPY $1 \mu M$

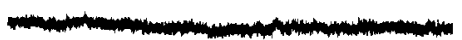

Figure 5. $\Lambda$, Bath application of $1 \mu \mathrm{M}$ NT induced an outward current on this C-type cell (upper trace), while NPY $(1 \mu \mathrm{M})$ had no effect (lower trace). Note that the effect of NT is slow in onset. The membrane potential was held at $-66 \mathrm{mV} . B$, NPY at $0.5 \mu \mathrm{m}$ induced an outward current on another C-type cell, while NT $(1 \mu \mathrm{M})$ was without effect. The membrane potential was held at $-66 \mathrm{mV}$. C, An inward current was evoked by application of $1 \mu \mathrm{M}$ NT on an A-type cell, while NPY had no effect. Note the action of NT is fast in onset and the different time scale.

Many NT-IR axonal terminals containing numerous synaptic vesicles and large dense-core vesicles (LDCVs) (90-125 nm in diameter) were observed in lamina II. They often made synaptic contact with NT-negative dendrites and cell bodies and less often, without synaptic specialization, with the central terminals of type I (electron-dense), and sometimes of type II (electronlucent) glomeruli in laminae II and III (see Ribeiro-da-Silva and Coimbra, 1982) (Fig. 6A-C). The type I glomeruli in contact with NT-IR axonal terminals were mainly located in lamina II, and most of these central terminal profiles contained densely packed synaptic vesicles and no or only few LDCVs (70-90 nm in diameter) (Fig. 6A). Occasionally NT-IR axonal terminals directly contacted the central terminals of type I glomeruli con-

taining many LDCVs $(90-145 \mathrm{~nm}$ in diameter) (Fig. 6B). Synaptic contacts between central terminals of type I glomeruli and NT-IR dendrites were rarely seen. The few type II glomeruli with direct contact to NT-IR terminals were mainly located in inner lamina II and the superficial lamina III (Fig. 6C) and sometimes contained a few LDCVs (70-90 nm in diameter). No synapses between glomeruli and NT-IR axonal terminals were observed, but sometimes a NT-IR axonal terminal in contact with a glomerulus synapsed on a dendrite in synaptic contact with the same glomerulus (Fig. 6A).

Semiquantitative analysis showed 30 NT-IR nerve terminals in direct contact with the central terminals of glomeruli containing no or less than three LDCVs (70-90 nm in diameter), six NT-IR nerve terminals in direct contact with central terminals of glomeruli containing more than three LDCVs $(90-145 \mathrm{~nm}$ in diameter), while 142 NT-IR terminals made synaptic contact with dendrites and two with NT-negative axonal terminals.

In the control experiments for immunohistochemistry preabsorption with peptide completely abolished the immunostaining.

\section{Downregulation of expression of NT-R mRNA in DRGs after} peripheral axotomy

In situ hybridization histochemistry revealed that the number and distribution of NT-R mRNA-positive neuron profiles in the contralateral L4 and L5 DRGs after unilateral axotomy were not significantly different from those observed in control ganglia at all time intervals studied $(2,7,14,21$, and 28 d after axotomy) (Fig. 7A, Table 1). The number of NT-R mRNA-positive neurons was decreased $(1.7 \pm 0.8 \%)$ in the ipsilateral $\mathrm{L} 4$ and $\mathrm{L} 5$ DRGs $2 \mathrm{~d}$ and onwards $(7,14,21$, and $28 \mathrm{~d})$ after unilateral axotomy (Figs. $7 B, C$; 8; Table 1). In contrast, Y1 receptor mRNA was markedly increased in $57.1 \pm 4.1 \%$ of the large DRG neuron profiles, and the intensity of labeling was markedly reduced in small sensory neuron profiles (Fig. $7 D, E$ ) (see also Zhang et al., 1994).

Northern blot analysis revealed that the NT-R probes hybridized to a single hybridizing transcript of approximately $3.8 \mathrm{~kb}$ in rat control DRGs (Fig. 9). The size of the hybridizing mRNA was close to the size of the NT-R cDNA clones (Tanaka et al., 1990). The ${ }^{32} \mathrm{P}-$ labeled probe for the $\mathrm{Y} 1$ receptor hybridized to an approximately $2.5 \mathrm{~kb}$ mRNA species from normal DRGs (Fig. 9). The size of the hybridizing mRNA was close to the size of the Y1 receptor cDNA clones (Eva et al., 1990). After peripheral axotomy the NT-R probes hybridized to a single hybridizing transcript, and a decrease in the intensity of the hybridization signal was observed in the ipsilateral DRGs (Fig. 9). The size of the hybridizing mRNA was close to the size of the NT-R cDNA clones. The ${ }^{32} \mathrm{P}-$ labeled probe for the Y1 receptor hybridized to a single hybridizing transcript from ipsilateral DRGs (Fig. 9). The signal was stronger from axotomized DRGs (Fig. 9). The size of the hybridizing mRNA was close to the size of the $\mathrm{Y} 1$ receptor cDNA clones.

\section{Downregulation of expression of NT in dorsal horn neurons after peripheral axotomy}

In situ hybridization analysis of the normal and contralateral dorsal horns revealed many small NT mRNA-positive neurons in laminae II and III with the highest numbers in deep lamina II and superficial lamina III (Fig. 10). The distribution, number, and labeling intensity of NT mRNA-positive neurons in the contralateral superficial dorsal horn 7 and $14 \mathrm{~d}$ after unilateral sciatic nerve transection were similar to the ones in control spinal cords 

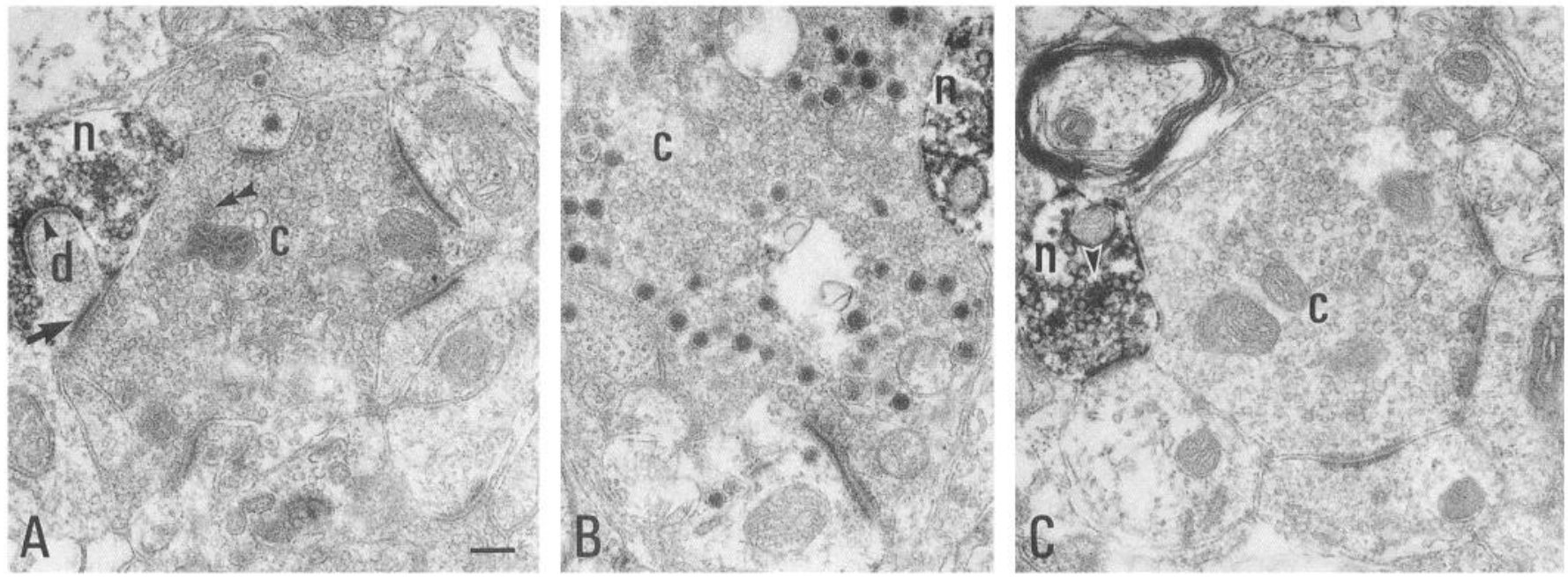

Figure 6. $A-C$, Electron micrographs of type I $(A, B)$ and type II $(C)$ glomeruli in outer $(A, B)$ and inner $(C)$ lamina II. $A$, An NT-positive axon terminal $(n)$ containing many synaptic vesicles makes synaptic contact (arrowhead) with an NT-negative dendrite $(d)$, which also receives a synapse (arrow) from a central terminal $(c)$ of type I which, in turn, is directly in contact with the NT-positive terminal. Note that only one single small LDCV (double arrowhead) is seen in the central terminal. B. An NT-positive axonal terminal $(n)$ is in contact with a central terminal $(c)$ of type I containing many LDCVs. $C$, A central terminal $(c)$ of type II directly contacts a NT-positive axonal terminal $(n)$ containing many synaptic vesicles and some LDCVs (arrowhead). Scale bar, $200 \mathrm{~nm}$ (all same magnification).
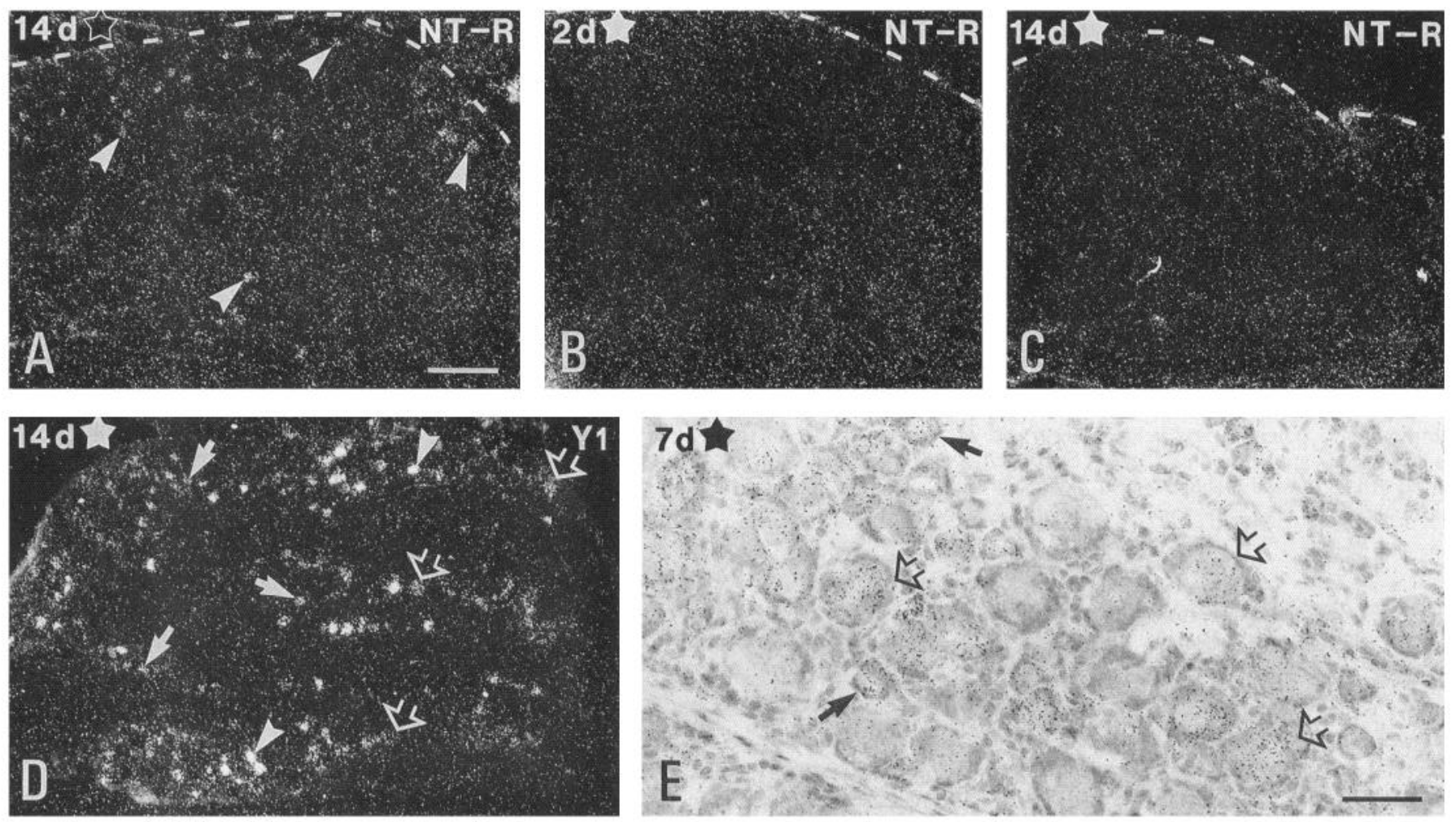

Figure 7. $A-E$, Dark-field $(A-D)$ and bright-field $(E)$ micrographs of contralateral $(A)$ and ipsilateral $(B-E)$ L5 DRGs $2(B), 7(E)$, and $14 \mathrm{~d}(A$, $C, D)$ after peripheral, unilateral axotomy hybridized with a probe for NT-R mRNA (NT-R) $(A-C)$ and for Y1 receptor mRNA (Y1) $(D, F)$. Weak labeling for NT-R mRNA is observed in some small neurons (arrowheads in A) in the contralateral DRG. No labeling for NT-R mRNA is observed in ipsilateral DRGs $2(B)$ and $14(C) \mathrm{d}$ after axotomy. The Y1 receptor mRNA labeling is reduced in many small neurons (arrows in $D$ and $E$ ), but some strongly labeled small neurons can still be observed (arrowheads in D). Several labeled large neurons can be seen (open arrows in E) after axotomy. Stars indicate ipsilateral and open star contralateral DRGs. Scale bar: $200 \mu \mathrm{m}$ in $A-D ; 20 \mu \mathrm{m}$ in $E$. 


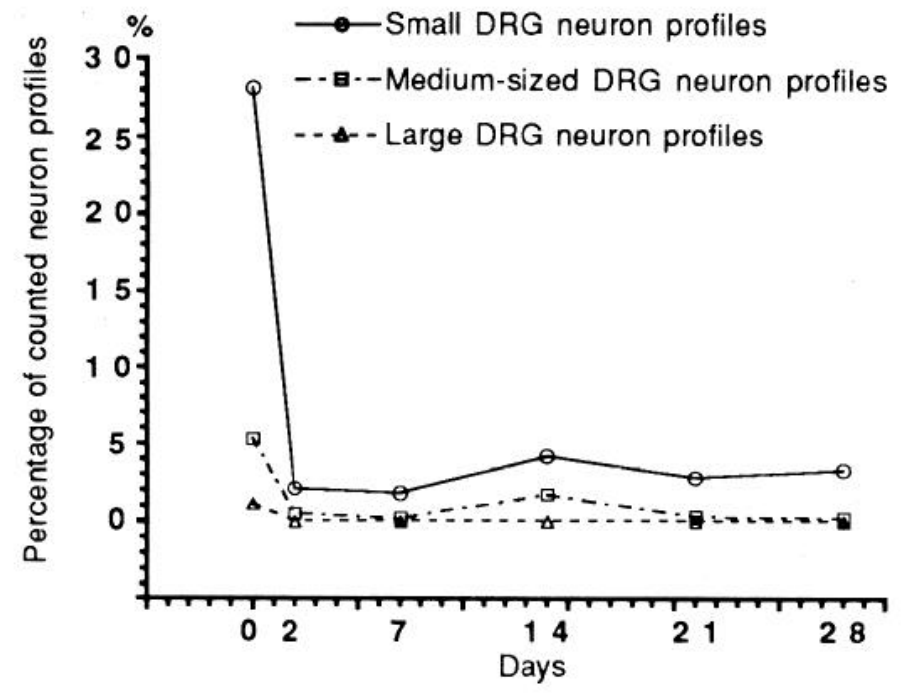

Figure 8. Diagram showing percentage of NT-R mRNA-positive small, medium-sized, and large neuron profiles in DRG neurons in control (day 0) and ipsilateral L5 DRGs 2, 7, 14, 21, and $28 \mathrm{~d}$ after sciatic nerve transection. Note dramatic decrease in labeled small neurons. Three control rats and three lesioned rats were analyzed. At least 550 neurons were counted in each DRG of each animal. Only means are shown. For standard error of mean (SEM), see Table 1.

(Figs. 10, 11A; Table 2). However, an exception was the medial field A1, where a decrease was observed contralaterally after 14 d (Table 2). In the ipsilateral dorsal horn the number of NT mRNA-positive neurons in the medial two fields (A1 and 2) was markedly reduced $7,14,21$, and $28 \mathrm{~d}$ after peripheral axotomy (Figs. 10, 11B; Table 2). The intensity of labeling for NT mRNA in the remaining cells in the dorsal horn neurons was also decreased, especially in the medial part of the dorsal horn (Fig. 10, Table 3).

Immunofluorescence staining showed that NT-IR fibers were concentrated in two bands with high fiber densities, one in lamina I and superficial part of lamina II and the other one in the deep part of lamina II and the superficial part of lamina III (Fig. $11 C, D)$. NT-IR neuronal cell bodies were mainly observed in the inner part of lamina II and the superficial part of lamina III (Fig. 11C,D). Scattered NT-IR nerve fibers were seen in laminae III and IV. After peripheral axotomy there was no marked change in NT-LI in the contralateral dorsal horn at any time (Fig. $11 E)$. There was a decrease in the number of NT-IR fibers and cell bodies in the medial part of laminae I and II (areas A1 and 2) of the ipsilateral dorsal horn $7 \mathrm{~d}$ after peripheral axotomy with more pronounced changes after 14 (Fig. $11 F$ ), 21, and 28 d. No marked effect of axotomy was observed on the scattered NT-IR nerve fibers in laminae III and IV.

Immunoelectron microscopy showed that the direct contacts observed in normal spinal cord (see above) between NT-IR boutons and primary afferents were rarely observed after axotomy. Occasionally, NT-IR nerve terminals, which contained many synaptic vesicles and some large vesicular structures, were seen near the axonal labyrinths that were composed of central primary afferent terminals and surrounding dendrites, axons, and glial processes (Fig. 12).

\section{Discussion}

Complementary distribution of NT-R and NPY-R mRNA in normal DRGs

The present results demonstrate that several, mainly small DRG neurons at the L4 and L5 levels express NT-R mRNA. These

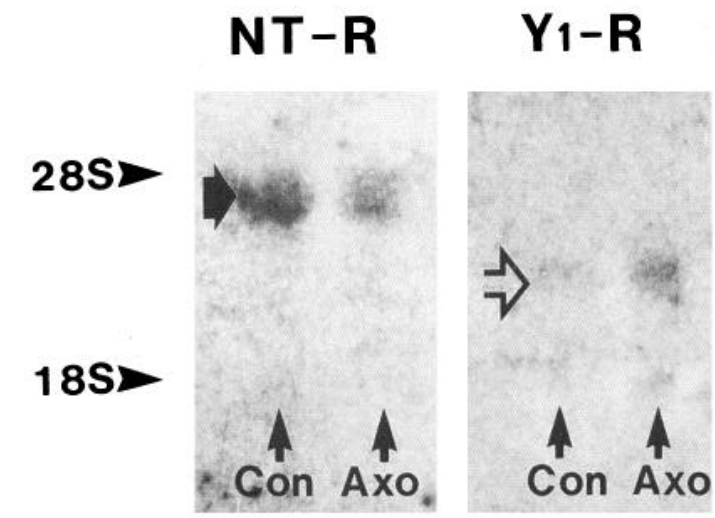

Figure 9. Northern blot analysis of total RNA from rat control L4/5 DRGs (Con) and L4/5 DRGs $14 \mathrm{~d}$ after sciatic nerve transection (Axo). ${ }^{32} \mathrm{P}$-labeled oligonucleotide probes complementary to the NT-R or Y1 subtype of NPY receptor were used. The NT-R blot shows a single band of approximately $3.8 \mathrm{~kb}$ size (solid arrow) from control and axotomized DRGs. Note decrease in hybridization signal after axotomy. The Y1 blot shows a single band of approximately $2.5 \mathrm{~kb}$ size (open arrow) from control and axotomized DRGs. The hybridization signal is increased after axotomy.

neurons represent a unique population that up till now has not been associated with a peptide or peptide receptor synthesis. Thus, we here show that the NT-R-positive neurons contain neither NPY Y1-R mRNA nor SOM mRNA. NPY Y1-R neurons have previously been shown to contain CGRP mRNA but not SOM mRNA (Zhang et al., 1994a), and a considerable proportion of the CGRP neurons has been shown to contain SP-LI (Gibson et al., 1984; Wiesenfeld-Hallin et al., 1984). SP neurons do not to any major extent overlap with SOM neurons in rat DRGs (Hökfelt et al., 1976; Tuchscherer and Seybold, 1985). From these cited studies and the present results the conclusion can be drawn that small DRG neurons in the rat essentially can be divided into four categories (1) CGRP + SP + NPY Y1-R neurons $(\sim 40 \%)$, (2) CGRP + NPY Y1-R neurons $(\sim 15 \%),(3)$ SOM neurons $(\sim 15 \%)$, and (4) NT-R neurons $(\sim 30 \%)$ (Fig. 13; see also Fig. $14 A, B)$. It is likely that the first group (CGRP + SP + NPY Y1-R) also expresses the opioid delta receptor (Dado et al., 1993). The NT-R mRNA-positive neurons may overlap with the early described fluoride-resistant acid phosphatase (FRAP)-positive neurons (Knyihar-Csillik and Csillik, 1981), since in normal rats they have been described to largely lack SOM- and SP-LIs (Nagy and Hunt, 1982).

Small sized primary sensory neurons are likely, at least in part, to be involved in nociception (see Burgess and Pearl, 1973; Zimmermann, 1976; Lynn, 1982; Willis and Coggeshall, 1991). In previous autoradiographic studies NT binding sites have been observed in the superficial dorsal horn of the cervical spinal cord (Young and Kuhar, 1981) and related to local dorsal horn neurons (Ninkovic et al., 1981). This is strongly supported by electrophysiological studies showing primarily depressive effects of NT on nociceptive and non-nociceptive dorsal horn neurons (Henry, 1982), but excitatory effects on dorsal horn neurons have also been reported (Miletic and Randic, 1979; Stanzione and Ziegelgänsberger, 1983). We could not detect any NT-R mRNA in the dorsal horn, but the mRNA levels in the individual neurons may be too low to be visualized with our present methodology or other subtypes of NT-Rs may exist in the dorsal horn (and DRGs). It should be emphasized that our methodology based on oligonucleotide probes presumably is less sensitive 


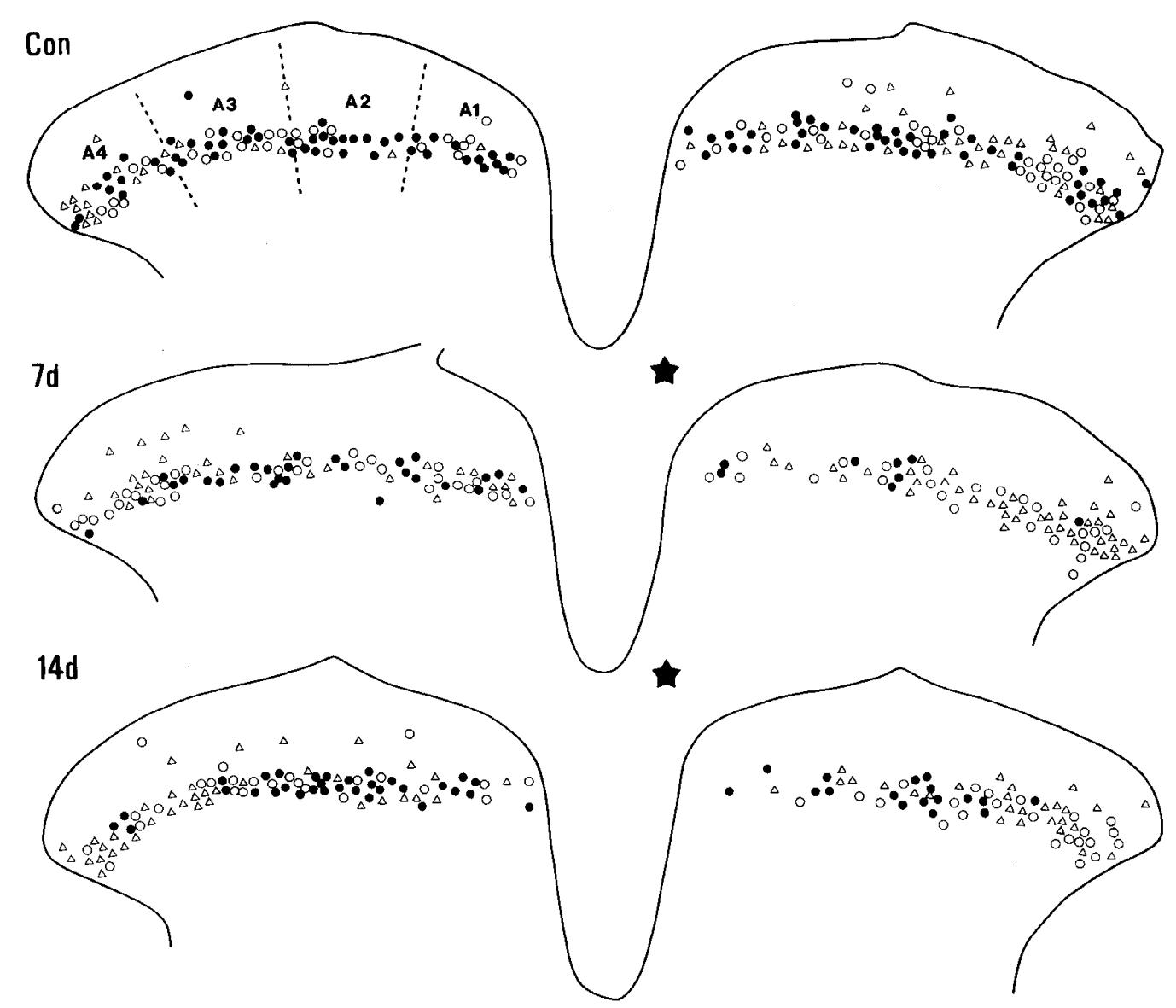

Figure 10. The distribution of NT mRNA-positive neurons (camera lucida drawing) taken from 10 transverse sections of L4 spinal cords of a control rat (Con), and $7(7 d)$ and $14(14 d) \mathrm{d}$ after unilateral sciatic nerve transection is shown. Stars indicate dorsal horn ipsilateral to axotomy. The solid line represents the boundary between gray and white matter. The dotted lines indicate four subfields (A1-A4) in the dorsal horn. Filled circles indicate intensely labeled cells, open circles moderately strongly labeled cells, and triangles lightly labeled cells. In the Al and A2 regions of the ipsilateral dorsal horn the number and intensity of NT mRNA-positive neurons is markedly reduced 7 and $14 \mathrm{~d}$ after axotomy.

than, for example, the riboprobe procedure, and we may therefore not detect all NT-R systems. The present results describing the presence of NT-R mRNA in about $30 \%$ of all L4/L5 DRG sensory neurons suggest that, in addition to local dorsal horn neurons, primary afferent terminals in the superficial, lumbar dorsal horn may have NT-Rs and thus be sensitive to NT. These receptors may be diluted by those present on local dorsal horn neurons, which may be one reason why no effect of dorsal rhizotomy was observed on NT binding in the dorsal horn (Ninkovic et al., 1981). Alternatively, the receptor protein may not be transported from the cell bodies to the terminals in the dorsal horn.

\section{The inhibitory effect of NT and NPY on separate subpopulations of small DRG neurons}

The C-type cells recorded in this study exhibited most of the known electrophysiological characteristics for this cell group. They had a high $R_{\text {in }}$, a low threshold current injection was required to excite a somatic action potential, and there was a lack of time-dependent rectification (Yoshida and Matsuda, 1979; To-

Table 2. Number of NT mRNA-positive neurons counted in four areas (A1-A4) of lamina II and superficial lamina III of control, contralateral (Contra), and ipsilateral (Ipsi) dorsal horn of L4L5 spinal cord of control rats and 7 and $14 \mathrm{~d}$ after axotomy

\begin{tabular}{|c|c|c|c|c|c|}
\hline \multirow[b]{2}{*}{ Area } & \multirow[b]{2}{*}{ Control } & \multicolumn{2}{|l|}{7 days } & \multicolumn{2}{|l|}{14 days } \\
\hline & & Contra & Ipsi & Contra & Ipsi \\
\hline A 1 & $17.3 \pm 0.9$ & $20.0 \pm 1.5$ & $5.7 \pm 0.9 * *$ & $11.3 \pm 1.5^{*}$ & $7.3 \pm 2.8^{*}$ \\
\hline $\mathrm{A} 2$ & $24.3 \pm 2.0$ & $21.0 \pm 4.6$ & $11.3 \pm 2.3^{*}$ & $22.7 \pm 3.0$ & $18.7 \pm 5.4$ \\
\hline A3 & $26.7 \pm 2.7$ & $27.3 \pm 3.9$ & $19.3 \pm 1.9$ & $27.7 \pm 0.7$ & $23.7 \pm 1.2$ \\
\hline A4 & $36.0 \pm 1.7$ & $29.0 \pm 1.2$ & $35.0 \pm 2.7$ & $31.3 \pm 3.2$ & $28.3 \pm 1.8^{*}$ \\
\hline
\end{tabular}

Three rats for each time point and 10 transverse sections of $\mathrm{L} 4$ spinal cords were analyzed 

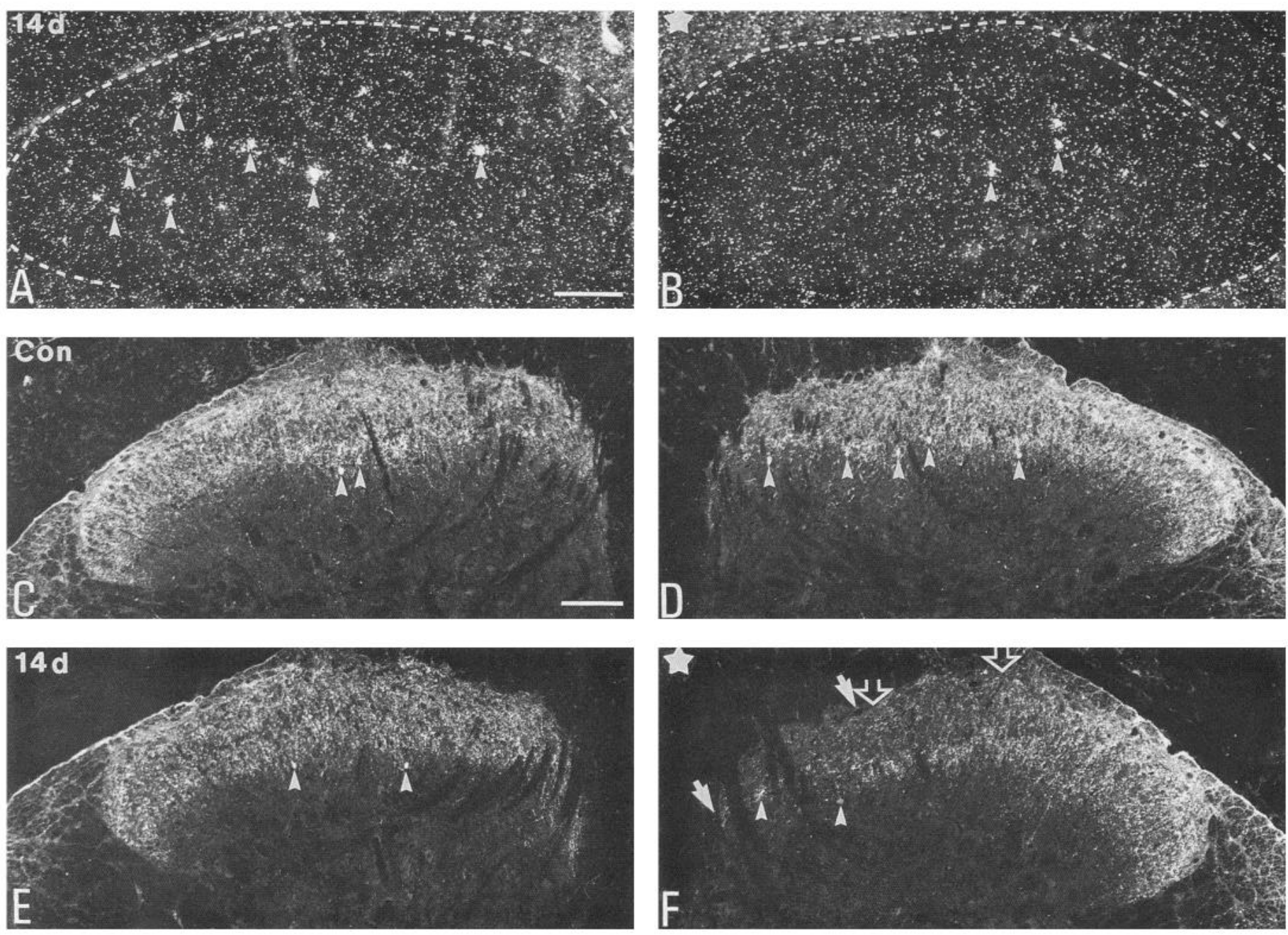

Figure 11. (A-F) $A$ and $B$, Dark-field micrographs of contralateral $(A)$ and ipsilateral (star) $(B)$ dorsal horn of L4 spinal cords $14 \mathrm{~d}$ after unilateral sciatic nerve transection, hybridized with probe for NT mRNA. In the contralateral dorsal horn NT mRNA-positive neurons (arrowheads in $A$, $C$ ) are observed in deep lamina II and superficial lamina III, and scattered in outer lamina II. In the ipsilateral dorsal horn, only a small number of NT mRNA-positive neurons is seen (arrowheads in $B$ ). $C-F$. Fluorescence micrographs of NT-LI in the superficial lumbar 4/5 dorsal horn of control rat $(C o n)(C, D)$ and $14 \mathrm{~d}(14 d)(E$ and $F)$ after unilateral sciatic nerve transection. Star indicates ipsilateral dorsal horn. NT-positive fibers are seen in the superficial laminae with a weak intensity in middle lamina II $(C, D)$. NT-positive neurons (arrowheads in $C, D)$ are seen in deep lamina II and superficial lamina III. Fourteen days after axotomy, NT-LI is markedly reduced in field A1 (between arrows) and A2 (between open arrows) (compare $F$ with $E$ ). Scale bars, $100 \mu \mathrm{m}$ (same magnification for $C-F$ ).

dorovic and Anderson, 1990, 1992; Waddell and Lawson, 1990). Although time-dependent rectification has been reported in C-type cells (Yoshida and Matsuda, 1979), it has primarily been observed in A-type cells (Harper and Lawson, 1985a,b). These authors provided evidence for this association by combining intracellular recording and dye-injection techniques. Thus, (1) peripheral $\mathrm{C}$ fibers belong to DRG neuronal somata in the size range of the small dark cell population, (2) the peripheral $\mathrm{A} \alpha$

Table 3. The number of densely (D), moderately (M), and lightly (L) labeled NT mRNA-positive neurons in four areas (A1-A4) of lamina II and superficial lamina III of dorsal horn of L4-L5 spinal cord of control rats and rats 7 and $14 \mathrm{~d}$ after axotomy

\begin{tabular}{|c|c|c|c|c|c|c|c|c|c|}
\hline \multirow[b]{2}{*}{ Area } & \multicolumn{3}{|l|}{ Control } & \multicolumn{3}{|l|}{7 days } & \multicolumn{3}{|l|}{14 days } \\
\hline & $\mathrm{D}$ & $\mathrm{M}$ & $\mathrm{L}$ & $\mathrm{D}$ & $\mathrm{M}$ & $\mathrm{L}$ & $\overline{\mathrm{D}}$ & $M$ & $\mathrm{~L}$ \\
\hline A1 & $7.7 \pm 1.2$ & $5.7 \pm 1.2$ & $4.0 \pm 0.6$ & $2.0 \pm 0.6^{* *}$ & $1.0 \pm 0.8^{*}$ & $2.7 \pm 1.2$ & $2.7 \pm 1.8^{*}$ & $1.0 \pm 0.6^{*}$ & $3.7 \pm 1.3$ \\
\hline $\mathrm{A} 2$ & $11.7 \pm 1.8$ & $3.7 \pm 0.3$ & $9.9 \pm 0.1$ & $2.0 \pm 1.0^{* *}$ & $3.0 \pm 1.0$ & $6.3 \pm 2.3$ & $8.3 \pm 2.6$ & $4.0 \pm 1.5$ & $6.3 \pm 2.3$ \\
\hline A3 & $8.7 \pm 0.3$ & $8.3 \pm 1.8$ & $9.7 \pm 2.9$ & $4.7 \pm 1.2 *$ & $3.7 \pm 1.2$ & $11.0 \pm 1.5$ & $6.7 \pm 1.3$ & $6.0 \pm 0.6$ & $11.5 \pm 1.3$ \\
\hline A4 & $8.3 \pm 1.7$ & $16.3 \pm 0.7$ & $11.3 \pm 0.3$ & $4.3 \pm 1.8$ & $8.7 \pm 1.5^{\text {*2* }}$ & $22.0 \pm 1.5^{\text {*** } * \text { * }}$ & $2.7 \pm 0.9^{*}$ & $9.7 \pm 0.7 * *$ & $16.0 \pm 1.7^{*}$ \\
\hline
\end{tabular}

This table is based on the same sections as Table 2 (see Table 2 for further details).

$* p<0.05$.

$* * p<0.01$. 


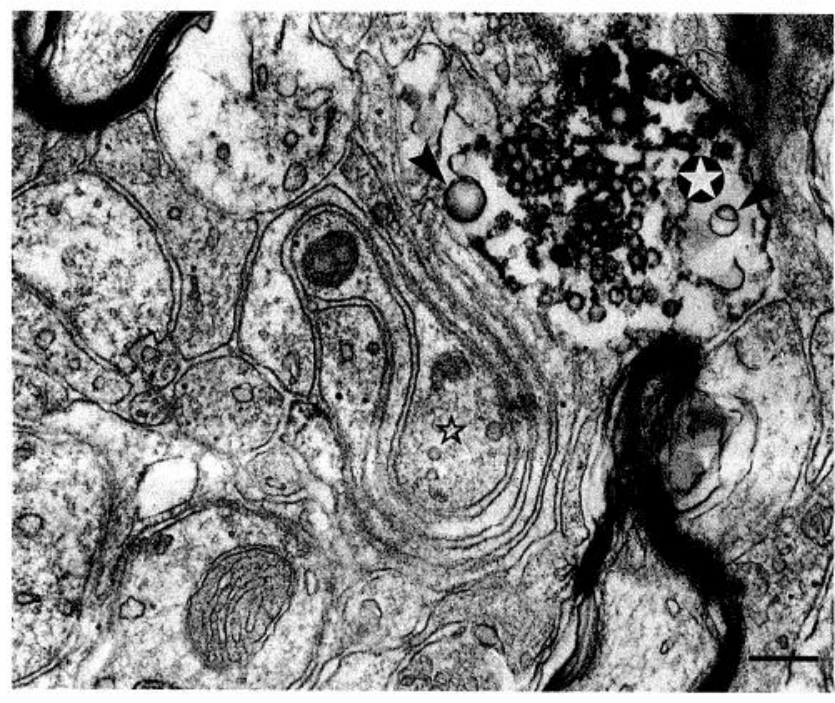

Figure 12. Electron micrograph showing a NT-IR nerve terminal (star) close to an axonal labyrinth composed of a central terminal (open star) and surrounding neuronal and glia processes in lamina II of ipsilateral dorsal horn $14 \mathrm{~d}$ after sciatic nerve section. The NT-IR nerve terminal contains many synaptic vesicles and some large vesicular structures (arrowheads). Scale bar, $200 \mathrm{~nm}$.

and $\mathrm{A} \beta$ fibers belong to neuronal somata with a mean size and size range similar to neurons in the large, light cell population, and (3) the mean size of somata with peripheral A $\delta$ processes falls between the mean sizes of the two main morphological cell

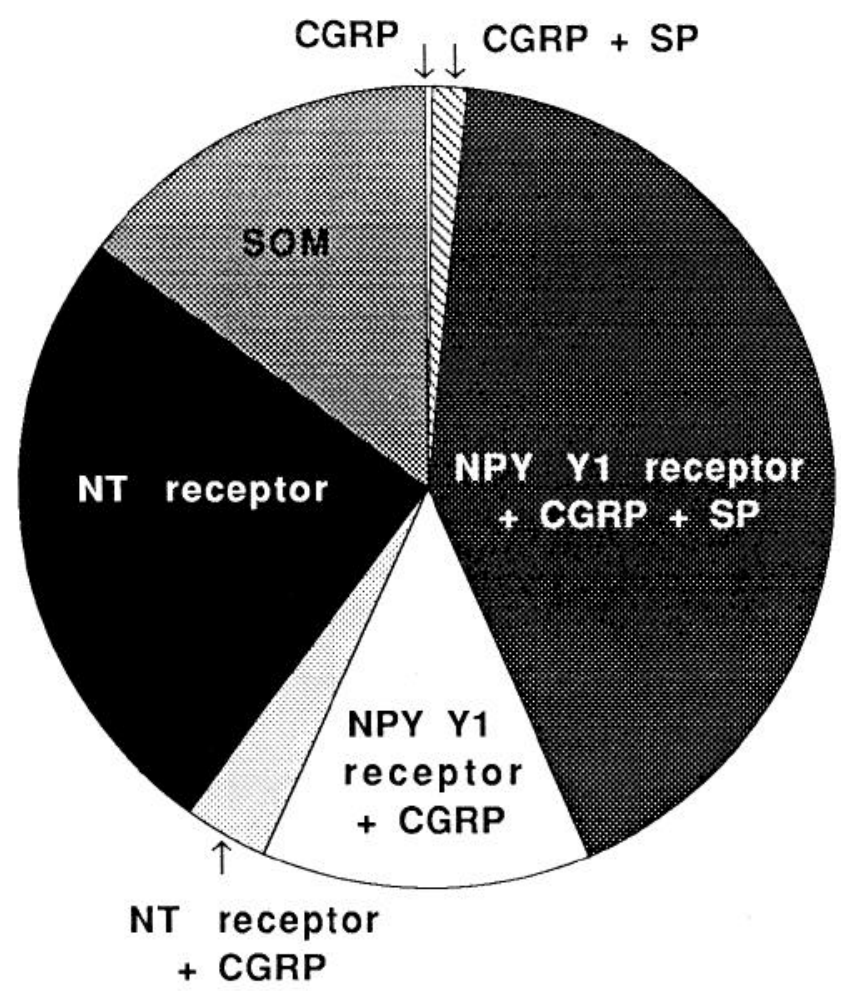

Figure 13. Schematic illustration of proportion and colocalization of mRNAs for the NT receptor, the NPY Y1 receptor, CGRP, SP, and SOM in small DRG neurons. Note the three major categories characterized by mRNAs for the NPY Y1 receptor, the NT receptor, and SOM, respectively. There are small overlaps between these three groups.

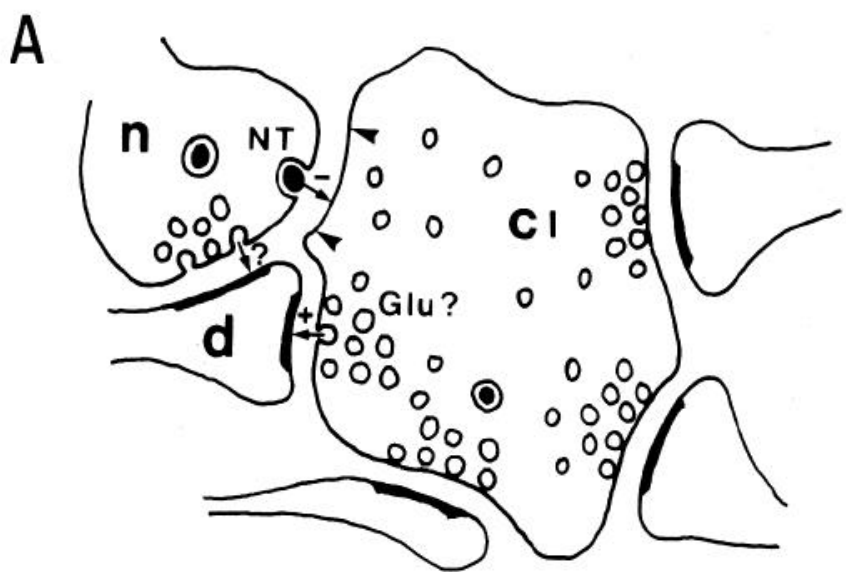

B

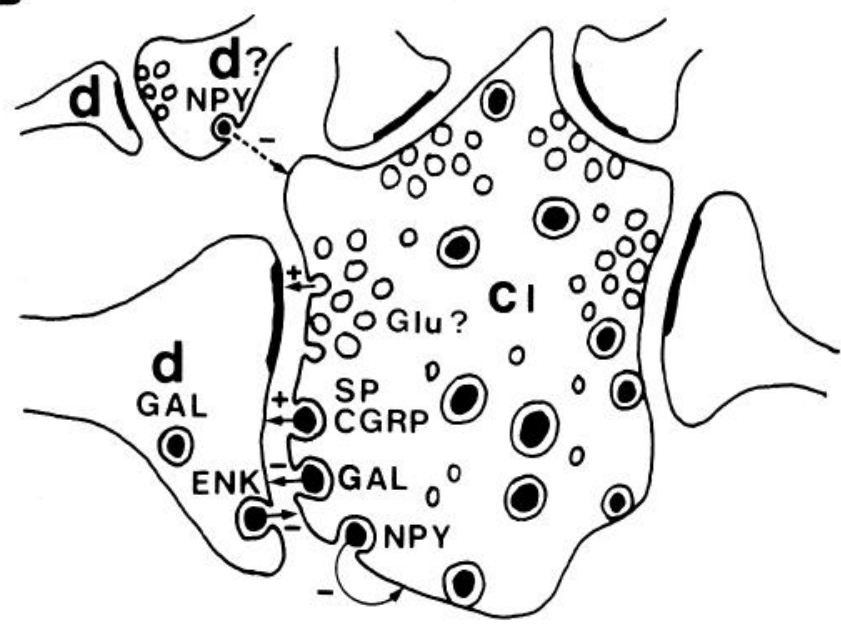

Figure 14. Schematic illustration of the relation of an NT-positive nerve ending $(n)$ of dorsal horn neurons to type I central terminals $(C I)$ of glomeruli as shown in this article $(A)$. For comparison, the relation of NPY-positive dendrite-like structures to a type I CI is shown as found in a previous study (see Zhang et al., 1994a), and references therein) (B). A, Direct contacts (between arrowheads) without synaptic specializations between a NT-positive nerve endings $(n)$ of dorsal horn neurons and a type I central terminal $(C I)$ of a glomerulus, possibly exerting an inhibitory influence (see Electrophysiological analysis). These central terminals rarely contain LDCVs and thus presumably have low amounts of peptides. They may correspond to the terminals of NT-R-positive small DRG neurons described in this study. Note that the NT-positive nerve endings can make a synaptic contact with a dendrite $(d)$, which in turn is postsynaptic to the central terminal. $B$, The most frequent NPY-positive structure of local dorsal horn origin are dendrite-like structures $(d$ ?) that can only be seen at some distance from the CIs of glomeruli, which presumably are rich in NPY Y1 receptors, as well as SP, CGRP, and GAL. NPY may, therefore, act on primary afferents at distance, alternatively even the low levels of NPY produced in normal small DRG neurons (Zhang et al., 1993b) could act on autoreceptors. In contrast, enkephalin $(E N K)$ dendrites, presumably also containing GAL, directly contact the CIs of glomeruli, which presumably contain delta-opioid receptor. Glutamate (Glu) may be the classic transmitter in both afferents. The arrows indicate the directions of transmission of Glu and peptides based on the locations of their receptors. Dotted arrows show hypothetical interaction. + indicates excitatory and - inhibitory effect.

types (Harper and Lawson, 1985a,b). Based on these findings we have tentatively assigned the C-type cell recorded in the present study as small DRG cells and the A-type cell as large and medium-sized cells.

Electrophysiological studies on other systems have revealed 
three effects of NT on neurons (see Shi and Bunney, 1992). II most areas of the CNS an excitatory effect of NT was observed, and inhibitory effects were less common. In some cases modulatory effects of NT were recorded; for example, NT attenuates dopamine-induced inhibition of midbrain dopamine neurons (Seutin et al., 1989; Shi and Bunney, 1992). In the spinal dorsal horn, NT attenuates (Henry, 1982), while in the hypothalamus (Baldino and Wolfson, 1985) NT potentiates glutamate-induced excitation. In the present study, under voltage clamp conditions, an inhibitory effect of NT was observed on small DRG cells via an outward current only, and this effect was weak and slow in onset, in agreement with the presence of NT-R mRNA in small DRG sensory neurons. In contrast, the major effect of NT on large neurons was excitatory, evoking an inward current. This effect was stronger than seen on small neurons and had a fast onset. The different effect of NT on the small and large DRG neurons could be due to presence of two different types of NT receptors. However, it is also possible that activation of the same type of receptor is coupled to different second-messenger systems.

The distinct differences in distribution of NT-R and NPY Y1-R mRNAs suggest that the peptides NT and NPY act on two separate populations of small DRG neurons. In agreement, our electrophysiological study indicates that C-type cells might be exclusively sensitive to one of the two peptides NT and NPY, whereas some other C-type cells were not sensitive to any of them. Thus, NPY evoked an outward current in some small as well as some large DRG neurons but had no effect on the neurons that responded to NT. Conversely, NT did not affect the neurons responding to NPY. Thus, the small DRG neurons may chemically and functionally be divided into NPY-sensitive, NTsensitive, and NPY/NT-insensitive populations. The latter may correspond to the SOM DRG neurons.

Many behavioral, neurophysiological, and pharmacological studies have defined functional roles of NT and NPY. Earlier studies have shown presence of high affinity ${ }^{12.5}$ I-NPY binding sites on DRG neurons (Walker et al., 1988; Kar and Quirion, 1992), and there is a strong correlation between presence of SP and NPY-R in DRG neurons in normal rats (Zhang et al., 1994a). Moreover, Walker et al. (1988) have shown that NPY can inhibit the depolarization-induced release of SP from DRG cells in vitro, and Duggan et al. (1991) have presented similar results in vivo. Furthermore, intrathecal injection of NPY causes a strong inhibition of spinal nociceptive reflexes in anesthetized rats (Hua et al., 1991). Also NT has been shown to have antinociceptive effects (Clineschmidt and McGuffin, 1979; Yaksh et al., 1982; Spampinato et al., 1988). Intrathecal administration of NT results in an increase in the nociceptive threshold as measured in the hot plate test and an increase in the latency in the acetic acid-induced writhing response (Yaksh et al., 1982; Spampinato et al., 1988). However, other studies have only reported hypothermia after intrathecal injection of NT (Martin et al., 1981; Clineschmidt et al., 1982).

\section{NT-IR spinal neurons might be the major source of NT acting on DRG neurons}

The fact that NT apparently is not produced at any substantial levels in normal DRG neurons strongly suggest that NT-R expressed by these neurons is target for NT released from central neurons. In fact, numerous NT immunoreactive cell bodies and a dense NT immunoreactive fiber plexus are present in the dorsal horn (Uhl et al., 1979; Gibson et al., 1981; Hunt et al., 1981;
Ninkovic et al., 1981; Seybold and Elde, 1982; Seybold and Maley, 1984; Todd et al., 1992; Proudlock et al., 1993). Seybold and Maley (1984) have shown that NT-IR boutons often form synapses with local dorsal horn neurons, and we show symmetrical synaptic contacts of NT terminals on dendrites in synaptic contact with a primary afferent (Fig. 14A). However, here we emphasize NT-IR axoaxonic contacts with primary afferents (Fig. 14A). Thus, the present electron microscopic results show that many NT-IR axonal terminals in lamina II and in the superficial lamina III directly contact, without synaptic specializations, the central terminal of both type I and type II glomeruli (Ribeiro-da-Silva and Coimbra, 1982). Most of these glomeruli are type I and contain no or only few small LDCVs, indicating that these DRG neurons produce no or only low levels of neuropeptide (as discussed above, NT-R mRNA-positive DRG neurons contain neither CGRP, nor SP nor SOM). The central terminals of type I glomeruli emanate from unmyelinated primary afferents, and type II glomeruli from myelinated primary afferents (Light and Perl, 1979; Ribeiro-da-Silva and Coimbra, 1982). Thus, NT axonal terminals often directly contact central terminals of small DRG neurons with apparently low levels of peptides, and sometimes the terminals of large DRG neurons. The close contact may allow nonsynaptically released NT to act on receptors on primary afferents. In fact, it is likely that peptides are released extrasynaptically (see Thureson-Klein and Klein, 1990) and diffuse extracellularly (see Fuxe and Agnati, 1991). It is therefore possible that the primarily antinociceptive effects of NT described above is related to a direct action on primary afferents. However, even if we have shown that NT-R mRNA is expressed in DRG neurons and that there are NT sensitive DRG neurons, it remains to be demonstrated that the NT receptor protein is transported centrally to the dorsal horn and is incorporated into the membrane.

Recently, it has been demonstrated that NT is present in glutamatergic neurons in the superficial dorsal horn of the rat (Todd et al., 1994). We here show that at least some NT-IR nerve terminals in direct contact with primary afferent terminals can synapse on dendrites that also receive a synapse from the same primary afferent terminals (Fig. 14A). Our electrophysiological results indicate that NT mainly has an inhibitory effect on small neurons in DRGs. It may be speculated that NT/glutamate boutons (see Todd et al., 1994) release both components, whereby glutamate acts excitatory primarily at the axodendritic synapse, and NT inhibits the adjacent primary afferent central terminal (Fig. 14A).

\section{Downregulation of NT system at spinal level after peripheral axotomy}

Peripheral axotomy, which may result in pathological pain (see Devor, 1984), has been shown to cause dramatic changes in expression of peptides and other messenger-related molecules in primary sensory neurons, perhaps attenuating nociceptive transmission in the dorsal horn and promoting survival and regeneration (see Hökfelt et al., 1994). With regard to NPY, peripheral nerve injury causes a dramatic increase in peptide levels (Wakisaka et al., 1991, 1992), and NPY receptor mRNA shows a biphasic response (Zhang et al., 1994a). Axotomy causes downregulation of two NT systems. Thus, after peripheral axotomy NT-R synthesis in DRG neurons decrease, and in the dorsal horn both NT-LI and NT mRNA are markedly reduced, especially in the medial areas where primary afferent from the sciatic nerve terminate (Molander and Grant, 1985; LaMotte et al., 1991). 
Moreover, after axotomy direct contacts between NT boutons and primary afferents can rarely be seen. Thus, it appears as if there is a pronounced 'disengagement' of NT influence on the primary afferents in the dorsal horn after axotomy, suggesting that possible effects of NT on injured sensory neurons are attenuated. Since expression of NPY Y1 receptor in small DRG neurons is reduced, the inhibitory effects on another subpopulation of small DRG neurons might also be attenuated. So, in general terms the regulation of NT-R and NPY-R in small DRG neurons after axotomy favors a decrease in inhibition of injured small DRG neurons. However, the downregulation of NT- and NPY-R mRNAs may be a consequence of the general role that neurons after injury downregulate compounds related to chemical transmission processes and upregulate those important for repair (Barron, 1983). Some of these mechanisms may also occur in primates, since there is a marked decrease of NT-LI in the ipsilateral superficial dorsal horn of monkey spinal cord after peripheral axotomy (Zhang et al., 1993a).

We conclude that NT-R and NPY-R are expressed in two separate subpopulation of small DRG neurons and perhaps in their terminals (Fig. 14A,B). NT and NPY have inhibitory effects on these two population of small DRG neurons, respectively. NT-IR spinal neurons in the superficial dorsal horn may be the major source of NT acting on primary afferent terminals in the superficial dorsal horn. Peripheral axotomy causes a decrease in NT levels in the superficial dorsal horn together with the downregulation of expression of NT-Rs in small DRG neurons, suggesting that the effects of NT at spinal level are attenuated after nerve injury.

Note added in proof: We have recently found that the NPY Y1-R may not be transported centrifugally, but may remain as a somatic receptor in the DRG neurons. It may be activated by circulating NPY released from sympathetic nerves and adrenal medulla (Zhang et al., 1994b).

\section{References}

Amara SG, Arriza JL, Leff SE, Swanson LW, Evans RM, Rosenfeld MG (1985) Neuropeptide homologous to calcitonin gene-related peptide. Science 229:1094-1097.

Baldino JF, Wolfson B (1985) Postsynaptic actions of neurotensin on preoptic-anterior hypothalamic neurons in vitro. Brain Res 325:161170.

Barron KD (1983) Comparative observations on the cytological reactions of central and peripheral nerve cells to axotomy. In: Spinal cord reconstruction (Kao CC, Bunge RP, Reier PJ, eds), pp 7-40. New York: Raven.

Burgess PR, Pearl ER (1973) Cutaneous mechanoreceptors and nociceptors. In: Handbook of sensory physiology (Iggo A, ed), pp 29 78. Berlin: Springer.

Carraway R, Leeman SE (1973) The isolation of a new hypothalamic peptide, neurotensin, from bovine hypothalamus. J Biol Chem 248 6854-6861.

Carraway R, Leeman SE (1975) The synthesis of neurotensin. J Biol Chem 250:1912-1918.

Clineschmidt BV, McGuffin JC (1979) Neurotensin: antinocisponsive action in rodents. Eur J Pharmacol 54:129-139.

Clineschmidt BV, Martin GE, Veber DF (1982) Antinocisponsive effects of neurotensin-related peptides. Ann NY Acad Sci 400:283306

Dado RJ, Lay PY, Loh HH, Elde R (1993) Immunofluorescent identification of a delta $(\delta)$-opioid receptor on primary afferent nerve terminals. Neuroreport 5:341-344.

Dagerlind A, Friberg K, Bean AJ, Hökfelt T (1992) Sensitive mRNA detection using unfixed tissue: combined radioactive and non-radioactive in situ hybridization histochemistry. Histochemistry 98:39-49.

Devor M (1984) The pathophysiology and anatomy of damaged nerve.
In: Textbook of pain (Wall PD, Melzack R, eds), pp 49-64. Fdinburgh: Churchill Livingston.

Duggan AW, Hope PJ, Lang CW (1991) Microinjection of neuropeptide $\mathrm{Y}$ into the superficial dorsal horn reduces stimulus evoked re lease of immunoreactive substance $\mathrm{P}$ in the anesthetized cat. Neuroscience 44:733-740.

Elde R, Schalling M, Ceccalelli S, Nakanishi S, Hökfelt T (1990) Localization of neuropeptide receptor $m R N A$ in rat brain: initial observations using probes for neurotensin and substance $P$ receptors. Neurosci Lett 120:134-138.

Emson PC, Goedert M, Mantyh PW (1985) Neurotensin containing neurons. In: Handbook of chemical neuroanatomy, Vol 4, GABA and neuropeptides in the CNS, Pt 1 (Björklund A, Hökfelt T, eds), pp 355-405. Amsterdam: Elsevier.

Eva C, Keinänen K, Monyer H, Seeburg P, Sprengel R (1990) Molecular cloning of a novel $\mathrm{G}$ protein-coupled receptor that may belong to the neuropeptide receptor family. FEBS Lett 271:81-84.

Frey P, Lis M, Coward DM (1988) Neurotensin concentrations in rat striatum and nucleus accumbens: further studies of their regulation. Neurochem Int 12:33-38.

Fuxe K, Agnati LF, eds (1991) Advances in neuroscience, Vol I, Volume transmission in the brain. New York: Raven.

Gibson SJ, Polak JM, Bloom SR, Wall PD (1981) The distribution of nine peptides in rat spinal cord with special emphasis on the substantia gelatinosa and on the area around the central canal (lamina X). J Comp Neurol 201:65-79.

Gibson SJ, Polak JM, Bloom SR, Sabate IM, Mulderry PM, Ghatei MA, McGregor GP, Morrison JFB, Kelly JS, Evans RM, Rosenfeld MG (1984) Calcitonin gene-related peptide immunoreactivity in the spinal cord of man and of eight other species. J Neurosci 4:31013111.

Giuffrida R, Rustioni A (1992) Dorsal root ganglion neurons projecting to the dorsal column nuclei of rats. J Comp Neurol 316:206-220.

Goodman RH, Aron DC, Ross BA (1989) Rat pre-prosomatostatin. J Biol Chem 258:5570-5573.

Harper AA, Lawson SN (1985a) Electrical properties of rat dorsal root ganglion neurons with different peripheral nerve conduction velocities. J Physiol (Lond) 359:47-63.

Harper AA, Lawson SN (1985b) Conduction velocity is related to morphologic cell type in rat dorsal root ganglion neurons. J Physiol (Lond) 359:31-46.

Henry JL (1982) Electrophysiological studies on the neuroactive properties of neurotensin. Ann NY Acad Sci 400:216-227.

Hua XY, Boublik JH, Spicer MA, Rivier JE, Brown MR, Yaksh TL (1991) The antinociceptive effects of spinally administered neuropeptide $Y$ in the rat: systematic studies on structure-activity relationship. J Pharmacol Exp Ther 258:243-248.

Hunt SP, Kelly JS, Emson PC, Kimmel JR, Miller RJ, Wu J-Y (1981) An immunohistochemical study of neuronal populations containing neuropeptides or gamma-aminobutyrate within the superficial layers of the rat dorsal horn. Neuroscience 6:1883-1898

Hökfelt T, Elde R, Johansson O, Luft R, Nilsson G, Arimura A (1976) Immunohistochemical evidence for separate population of somatostatin-containing and substance P-containing primary afferent neurons in the rat. Neuroscience 1:131-136.

Hökfelt T, Zhang X, Wiesenfeld-Hallin Z (1994) Messenger plasticity in primary sensory neurons following axotomy and its functional implications. Trends Neurosci 17:22-30.

Jazin EE, Zhang X, Söderström S, Williams R, Hökfelt T, Ebendal T, Larhammar D (1993) Expression of peptide YY and mRNA for the NPY/PYY receptor of the Y1 subtype in dorsal root ganglia during rat embryogenesis. Dev Brain Res 76:105-113.

Kar S, Quirion R (1992) Quantitative autoradiographic localization of $\left[{ }^{125} \mathrm{I}\right]$ neuropeptide $\mathrm{Y}$ receptor binding sites in rat spinal cord and the effects of neonatal capsaicin, dorsal rhizotomy and peripheral axotomy. Brain Res 574:333-337.

Kislauskis E, Bullock B, NcNeil S, Dobner PR (1988) The rat gene encoding neurotensin and neuromedin $N$. Structure, tissue specific expression, and evolution of exon sequence. J Biol Chem 263:49634968.

Kitabgi P, Nemerotf CB, eds (1992) Annals of the New York Academy of Science, Vol 668, The neurobiology of neurotensin. New York: New York Academy of Science.

Knyihar-Csillik E, Csillik B (1981) FRAP: histochemistry of the primary nociceptive neuron. Prog Histochem Cytochem 14:1-137. 
Kobayashi RM, Brown M, Vale W (1977) Regional distribution of neurotensin and somatostatin in rat brain. Brain Res 126:584-588.

Krause JE, Chirgwin JM, Carter MS, Xu ZS, Hershey D (1987) Three rat preprotachykinin mRNAs encode the neuropeptides substance $\mathrm{P}$ and neurokinin A. Proc Natl Acad Sci USA 84:881-885.

I aMotte CC, Kapadia SF, Shapiro CM (1991) Central projections of the sciatic, saphenous, median, and ulnar nerves of the rat demonstrated by transganglionic transport of choleragenoid-HRP (B-HRP) and wheat germ agglutinin-HRP (WGA-HRP). J Comp Neurol 311: $546-562$.

Light AR, Perl ER (1979) Spinal termination of functionally identified primary afferent neurons with slowly conducting myelinated fibers. J Comp Neurol 186:133-149.

Lynn B (1982) Cutaneous sensation. In: Biochemistry and physiology of the skin (Goldsmith L, ed), pp 654-684. New York: Oxford UP.

Martin GE, Naruse T, Papp NL (1981) Antinociceptive and hypothermic actions of neurotensin administered centrally in the rat. Neuropeptides 1:447-454.

Miletic T, Randic M (1979) Neurotensin excites cat spinal neurons located in laminae I-III. Brain Res 169:600-604

Molander C, Grant G (1985) Cutaneous projection from the rat hindlimb foot to the substantia gelatinosa of the spinal cord studied by transganglionic transport of WG $\Lambda$-HRP conjugate. J Comp Neurol 237:476-484.

Nagy JI, Hunt SP (1982) Fluoride-resistant acid phosphatase-containing neurones in dorsal root ganglia are separate from those containing substance P or somatostatin. Neuroscience 7:89-97.

Ninkovic M, Hunt SP, Kelly JS (1981) Effect of dorsal rhizotomy on the autoradiographic distribution of opiate and neurotensin receptors and neurotensin-like immunoreactivity within the rat spinal cord. Brain Res 230:111-119.

Proudlock F, Spike RC, Todd AJ (1993) Immunocytochemical study of somatostatin, neurotensin, GABA, and glycine in rat spinal dorsal horn. J Comp Neurol 327:289-297.

Ribeiro-da-Silva A, Coimbra A (1982) Two types of synaptic glomeruli and their distribution in laminae I-III of the rat spinal cord. J Comp Neurol 209:176-186.

Seutin V, Massotte L, Dresse A (1989) Electrophysiological effects of neurotensin on dopaminergic neurons of the ventral tegmental area of the rat in vitro. Neuropharmacology 28:949-954.

Seybold VS, Elde RP (1982) Neurotensin immunoreactivity in the superficial laminae of the dorsal horn of the rat: I. Light microscopic studies of cell bodies and proximal dendrites. J Comp Neurol 205: $89-100$.

Seybold V, Maley B (1984) Ultrastructural study of neurotensin immunoreactivity in superficial laminae of the dorsal horn of the rat. Peptides 5:1179-1189.

Shi W-X, Bunncy BS (1992) Actions of neurotensin: a review of the electrophysiological studies. Ann NY Acad Sci 668:129-145.

Spampinato S, Romualdi P, Candeletti S, Cavicchini E, Ferri S (1988) Distinguishable effects of intrathecal dynorphins, somatostatin, neurotensin and s-calcitonin on nociception and motor function in the rat. Pain 35:95-104.

Stanzione P, Ziegelgänsberger W (1983) Action of neurotensin on spinal cord neurons in the rat. Brain Res 268:111-118.

Tanaka K, Masu M, Nakanishi S (1990) Structure and functional expression of the cloned rat neurotensin receptor. Neuron 4:847-854.

Thureson-Klein $\AA$, Klein RL (1990) Exocytosis from neuronal large dense-cored vesicles. Int Rev Cytol 121:67 126.

Todd AJ, Russell G, Spike RC (1992) Immunocytochemical evidence that GABA and neurotensin exist in different neurons in laminae II and III of rat spinal dorsal horn. Neuroscience 47:685-691.

Todd AJ, Spike RC, Price RF, Neilson M (1994) Immunocytochemical evidence that neurotensin is present in glutamatergic neuron in the superficial dorsal horn of the rat. J Neurosci 14:774-784.
Todorovic S, Anderson EG (1990) 5- $\mathrm{HT}_{2}$ and 5- $\mathrm{HT}_{3}$ receptors mediate two distinct depolarizing responses in rat dorsal root ganglion (DRG) neurones. Brain Res 511:71-79.

Todorovic S, Anderson EG (1992) Serotonin preferentially hyperpolarizes capsaicin-sensitive $C$ type sensory neurons by activating 5-HT ${ }_{1 \mathrm{~A}}$ receptors. Brain Res 585:212-218.

Tuchscherer MM, Seybold VS (1985) Immunohistochemical studies of substance $\mathrm{P}$, cholecystokinin-octapeptide and somatostatin in dorsal root ganglia of the rat. Neuroscience 14:593 605 .

Uhl GR (1990) Neurotensin receptors. In: Handbook of chemical neuroanatomy, Vol 9, neuropeptides in the CNS, Pt II (Björklund A, Hökfelt T, Kuhar M, eds), pp 443 453. Annsterdan: Elsevier.

Uhl GR, Goodman RR, Snyder SH (1979) Neurotensin-containing cell bodies, fibers and nerve terminals in the brainstem of the rat: immunohistochemical mapping. Brain Res 167:77-91.

Vrontakis ME, Peden LM, Duckworth ML, Friesen HG (1987) Isolation and characterization of a complementary DNA (galanin) clone from estrogen-induced pituitary tumor messenger MNA. J Biol Chem 262:16755-16758

Waddell PI, I awson SN (1990) Flectrophysiological properties of subpopulations of rat dorsal root ganglion neurons in vitro. Neuroscience 36:811-822.

Wakisaka S, Kajander KC, Bennett GJ (1991) Increased neuropeptide (NPY)-like immunoreactivity in rat sensory neurons following peripheral axotomy. Neurosci Lett 124:200-203.

Wakisaka S, Kajander KC, Bennett GJ (1992) Effects of peripheral nerve injuries and tissue inflammation on the levels of neuropeptide Y-like immunoreactivity in rat primary afferent neurons. Brain Res 598:349-352.

Walker MW, Ewald DA, Perney TM, Miller RG (1988) Neuropeptide $Y$ modulates neurotransmitter release and $\mathrm{Ca}^{2+}$ currents in rat sensory neurons. J Neurosci 8:2438-2446.

Wiesenfeld-Hallin Z, Hökfelt T, Lundberg JM, Forsmann WG, Reinecke M, Tschopp FA, Fischer JA (1984) Immunoreactive calcitonin generelated peptide and substance $P$ co-exist in sensory neurons to the spinal cord and interact in spinal behavioural responses of the rat. Neurossi T ett 52:199-204

Willis WD Jr, Coggeshall RE (eds) (1991) Sensory mechanisms of the spinal cord. New York: Plenum.

Yaksh TL, Schmauss C, Micevych PE, Abay EO, Go VLW (1982) Pharmacological studies on the application, disposition and release of neurotensin in spinal cord. Ann NY Acad Sci 400:228-242.

Yoshida S, Matsuda Y (1979) Studies on sensory neurons of the mouse with intracellular-recording and horseradish peroxidase-injection technique. J Neurophysiol 42:1134-1145.

Young WS, Kuhar MJ (1981) Neurotensin receptor localization by light microscopic autoradiography in the rat brain. Brain Res 206: $273-285$.

Zhang X, Ju G, Elde R, Hökfelt T (1993a) Effect of peripheral nerve cut on neuropeptides in dorsal root ganglia and the spinal cord of monkey with special reference to galanin. J Neurocytol 22:342-381.

Zhang X, Nicholas AP, Hökfelt T (1993b) Ultrastructural studies on peptides in the dorsal horn of the spinal cord. I. Coexistence of galanin with other peptides in primary afferents in normal rats. Neuroscience 57:365-384.

Zhang X, Wiesenfeld-Hallin Z, Hökfelt T (1994a) Effect of peripheral axotomy on expression of neuropeptide $Y$ receptor mRNA in rat lumbar dorsal root ganglia. Eur J Neurosci 6:43-57.

Zhang X, Bao L, Xu Z-Q, Kopp J, Arvidsson U, Elde R, Hökfelt T (1994b) Localization of neuropeptide Y Y1 receptors in the rat nervous system with special reference to somatic receptors on small dorsal root ganglion neurons. Proc Natl Acad Sci USA 91:1173811742.

Zimmermann M (1976) Neurophysiology of nociception. In: International review of physiology (Porter $\mathrm{R}$, ed), pp 179-221. Baltimore: University Park. 